GA-A15614

\title{
TURBOMACHINERY DESIGN CONSIDERATIONS FOR THE NUCLEAR HTGR-GT POWER PLANT
}

\author{
by \\ COLIN F. MCDONALD and MURDO J. SMITH
}

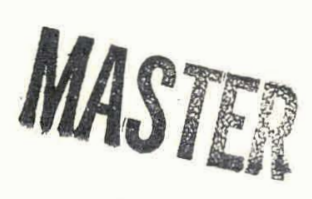




\section{DISCLAIMER}

This report was prepared as an account of work sponsored by an agency of the United States Government. Neither the United States Government nor any agency Thereof, nor any of their employees, makes any warranty, express or implied, or assumes any legal liability or responsibility for the accuracy, completeness, or usefulness of any information, apparatus, product, or process disclosed, or represents that its use would not infringe privately owned rights. Reference herein to any specific commercial product, process, or service by trade name, trademark, manufacturer, or otherwise does not necessarily constitute or imply its endorsement, recommendation, or favoring by the United States Government or any agency thereof. The views and opinions of authors expressed herein do not necessarily state or reflect those of the United States Government or any agency thereof. 


\section{DISCLAIMER}

Portions of this document may be illegible in electronic image products. Images are produced from the best available original document. 
This report was prepared as an account of work sponsored by the United States Government. Neither the United States nor the Department of Energy, nor any of their employees, nor any of their contractors, subcontractors, or their employees, makes any warranty, express or implied, or assumes any legal liability or responsibility for the accuracy, completeness or usefulness of any information, apparatus, product or process disclosed, or represents that its use would not infringe privately owned rights. 
GA-A15614

\section{TURBOMACHINERY DESIGN CONSIDERATIONS FOR THE NUCLEAR HTGR-GT POWER PLANT}

by

6

COLIN F. McDONALD and MURDO J. SMITH*

This is a preprint of a paper to be presented at the 25th ASME International Gas Turbine Conference, March 9-13, 1980, New Orleans, Louisiana, and to be published as an ASME Paper.

*United Technologies Corporation Power Systems Division South Windsor, Connecticut

Work supported by

Department of Energy Contract DE-AT03-76SF70046

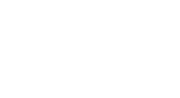

GENERAL ATOMIC PROJECT 6800 NOVEMBER 1979

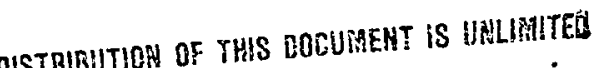




\section{TURBOMACHINERY DESIGN CONSIDERATIONS FOR THE NUCLEAR HTGR-GT POWER PLANT}

Colin F. McDonald

General Atomic Company

Preliminary Design Department

San Diego, California
Murdo J. Smith

United Technologies Corporation

Power Systems Division

South Windsor, Connecticut

\section{ABSTRACT}

For several years, design studies have been under way in the U.S.A. on a nuclear closed-cycle gas turbine plant (HTGR-GT). This paper presents design aspects of the helium turbomachine portion of these studies. Gas dynamic and mechanical design considerations are presented for helium turbomachines in the 400-MW(e) (non-intercooled) and 600-MW(e). (intercooled) power range. Design of the turbomachine is a key element in the overall power plant program effort, which is currently directed toward the selection of a reference HTGR-GT commercial plant configuration for the U.S. utility market. A conservative design approach has been emphasized to provide maximum safety and durability. The studies presented for the integrated plant concept outline the necessary close working relationship between the reactor primary system and turbomachine designers. State-ofthe-art technology from large industrial gas turbines developed in the U.S.A.; considered directly applicable to the design of a helium turbomachine, particularly in the areas of design methodology, performance, materials, and fabrication methods, is emphasized. 


\section{INTRODUCTION}

It is projected that by the end of the century, closed-cycle gas turbine (CCGT) power plants will be operational in tlie U.S.A. for electrical power generation because of (1) their adaptability to both nuclear and coal-fired heat sources, (2) their very high fuel utilization efftciency, (3) thetr potential for a high degree of reliability and avallability and low maintenance, and (4) their efficlent costeffective dry cooling where no cooling water is available. Further development is likely since this power conversion system seems well sulted to projected fusion and solar power plants of the twentyfirst century. The technology bases for closed-cycle gas turbine plants are well established by 40 yr of European operating experience. These European foss1l-fired plants, with electrical power outputs of up to $50 \mathrm{MW}(\mathrm{e})$, have demonstrated high degrees of availability and reliability, several of the mits having operated successfully for over $100,000 \mathrm{hr}$. The benefits of the nuclear gas turbine power plant are consistent with meeting national energy goals, and the high power conversion effictency potentlal satisfies increasingly important regource conservation demands. The helium turbomachine is the key element in the power conversion system, and this paper outlines the extensive program of design and development necessary to commerclalize the HTGR-GT plant for utility service in the loot decode of this century .

The design of a new power plant concept is an iterative process to.satisfy the vartouo performance, economic, safety, and rellabllity goals, and several plant configurations have evolved as the program has progressed in the last few years. The most recent design studies done by General Atomic Company are for a dry-cooled commercial plant in the 800- to 1200MW(e) power range (1). In these power plant studies intercooled and non-intercooled variants are being Invest1gated, both being based on dry cooling to ensure maximum site selection flexibility within the U.S.A. Following previously reported turbomachine work $(2-4)$, this paper addresses design activities currently in progress in support of the aforementioned power plant studies.

For an integrated plant with the power conversion system installed Inside the reactor vessel, the turbomachine cannot be treated as an isolated component, and indeed the design of the machine and the resolution of the gas flow paths and interfacing duct connections become an inherent part of the plant primary system development. In suppnrt of the plant configuration studies, turbomachine conceptual designs were done for machines in the 400-, 500-, and 600-MW(e) power classes for both intercooled and nonintercooled types. To span this power range and to

1llustrate the difference between the machine types, the 400-MW(e) (non-intercooled) and 600-MW(e) (interronled) design variants will be addressed in this paper.

To the non-specialist, gas turbines with the above power ratings may seem extremely large compared with open-cycle gas turbine experience, where units up to $100 \mathrm{MW}(\mathrm{e})$ have been built. In actuality, the high degree of pressurization associated with the closed-cycle system results in helium turbomachines that are similar in overall size to existing airbreathing industrial gas turbines, but of course exhibit much higlier specific power because of the high density and specific heat of the working fluid. State-of-the-art technology from large industrial gas turbines developed in the U.S.A., considered directly applicable to the design of a helium turbomachine, particularly in the areas of design methodology, performatic, midertals, and tabrication methods, is emphasized in this paper. 


\section{CLOSED-CYCLE GAS TURBINE BACKGROUND}

While the closed-cycle gas turbine is not well known in the U.S.A., it has demonstrated very high fuel utilization efficiencies and a high degree of reliability in the various European plants that have operated for almost a million hours. Since operation of the pioneer plant in 1939, 40 yr of experience have substantiated the claim that this prime-mover is we11 established (5). Some 20 plants were built for combined electrical power and heat production, and details of the operating experience for those known to still be in operation have been discussed previous $1 \mathrm{y}$ in Ref. 6 .

Since the helium turbomachine itself is the single most important power conversion loop component from the development standpoint, it is germane to review the applicability of established technologies. The industrial technology bases from which the turbomachine can benefit are shown in Fig. 1, which illustrates existing hardware. The emphasis in this figure relates to the formidable world-wide resources which, if utilized on an international cooperative basis, will make near-term introduction of the nuclear gas turbine plant a reality.

While helium turbomachines are not well known in the U.S.A., the array shown in Fig. 2 illustrates that helium axial flow turbomachines over an impressive power range have been constructed and operated successfully in Europe.

An important helium turbine plant is the fossil-fired 50-MW(e) Oberhausen 2 unit, which was built by Energieversorgung Oberhausen AG (EVO) in the Federal Republic of Germany $(7,8)$. In addition to providing electrical power $[50 \mathrm{MW}(\mathrm{e})]$ and district heating $[54 \mathrm{MW}(t)]$, the EVO plant is being used for tests intended to supply information [for the Euro- pean High Temperature Helium Turbine (HHT) Project] on the dynamics of the overall plant and on the longterm behavior of specific components. The selection of a relatively low system pressure for this power plant yields a large volumetric flow of the helium working fluid, and accordingly the actual equipment is comparable in size to a plant rated at over 200 MW(e). An appreciation for the size of the turbine is provided by Fig. 3, which shows details of the high-pressure rotor from the EVO plant. Another important plant is the high-temperature helium test facility (HHV) at Kernforschungsanlage in Jülich, the Federal Republic of Germany. The operation of this helium test plant represents a central test within the European HHT Project. Through this program, essential characteristics of the turbomachine are to be verified. The turbomachine consists of two turbine stages which produce 45 MW(e) and an eight-stage compressor which absorbs 90 MW(e), the difference being supplied by a 45-MW(e) synchronous motor. As a result of the compression work, the helium can be heated to $1000^{\circ} \mathrm{C}\left(1832^{\circ} \mathrm{F}\right)$, so a heater fired by fossil fuels has been eliminated. The combination of turbine and compressor and the thermodynamic conditions in the closed loop results in a turbomachine with dimensions representative of a helium turbine of approximately $300 \mathrm{MW}(\mathrm{e})$ output. The rotor for the HHV plant shown in Fig. 4 has a bearing span of $5.7 \mathrm{~m}(18.7 \mathrm{ft})$ and weighs about $60,000 \mathrm{~kg}$ (66 tons). The diameters of the bearings and seals are representative of a large commercial nuclear gas turbine plant.

A full account is given in Ref. 9 of the roles of the EVO plant and the HHV facility in the development of the European HHT Project. The turbomachine design activities outlined in the following sections of this paper are for the HTGR-GT program in the

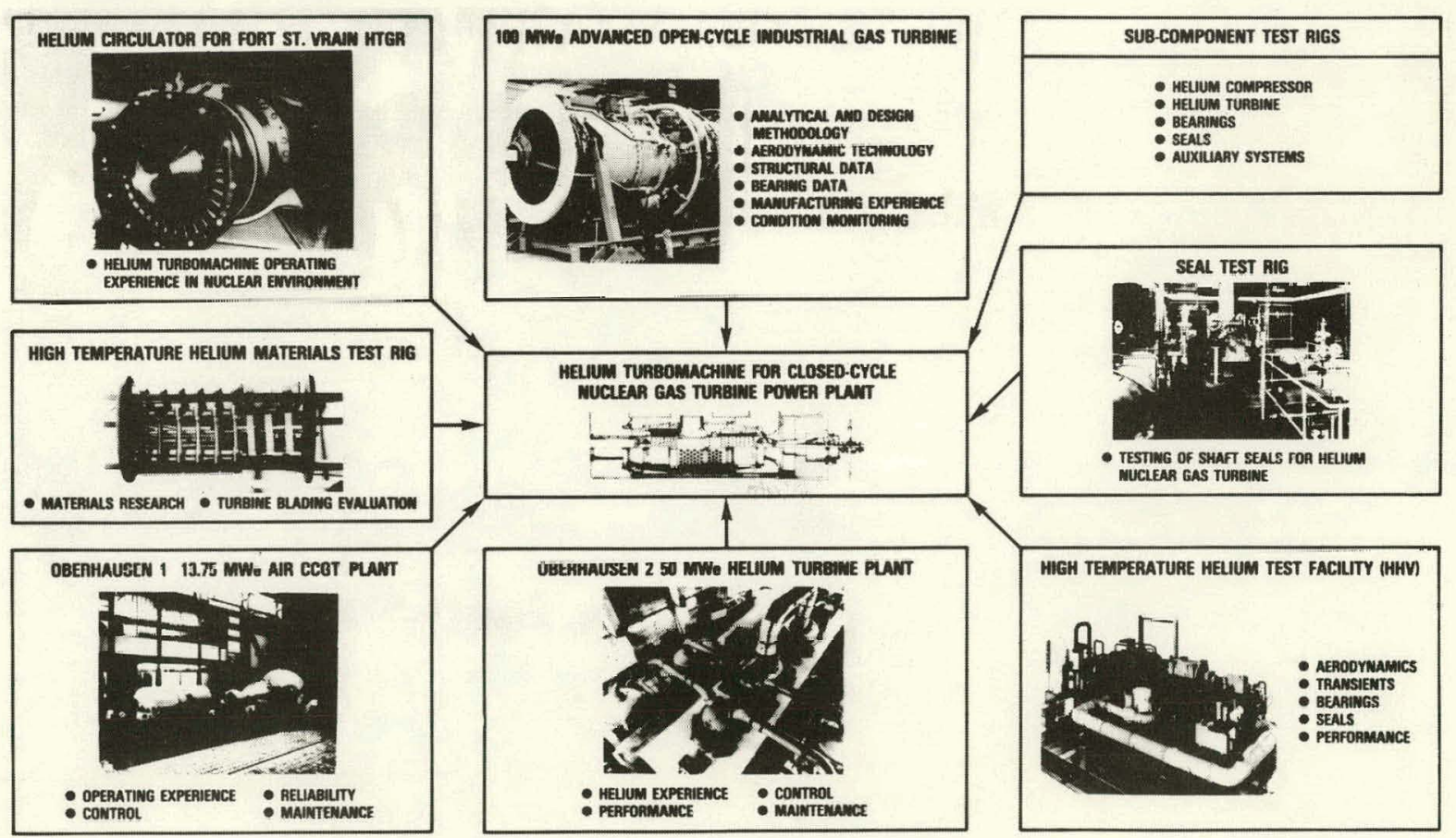

Fig. 1. Terhnnlogy bases for nuclear closed cyele helium 


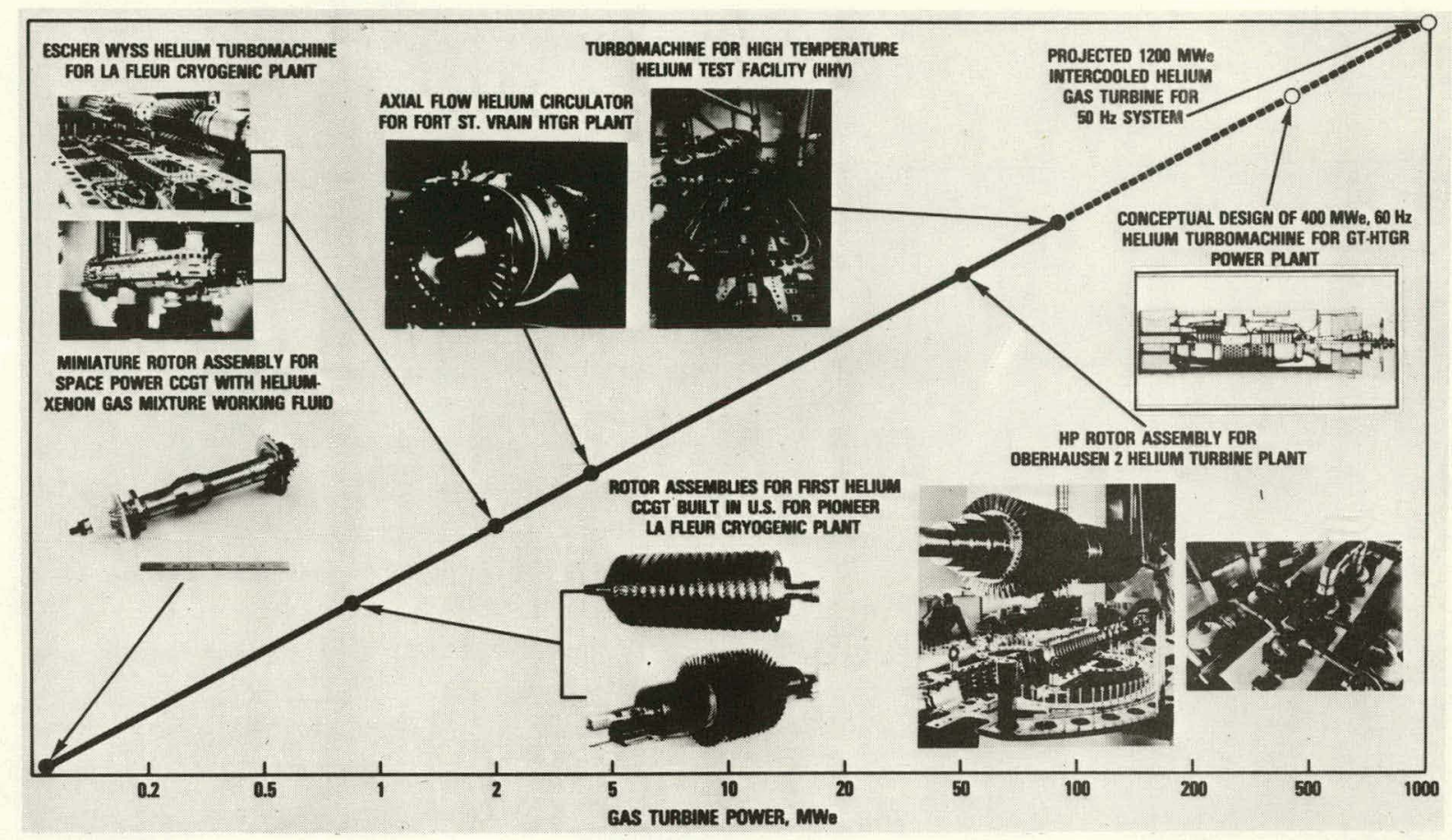

Fig. 2. Helium gas turbomachinery design evolution

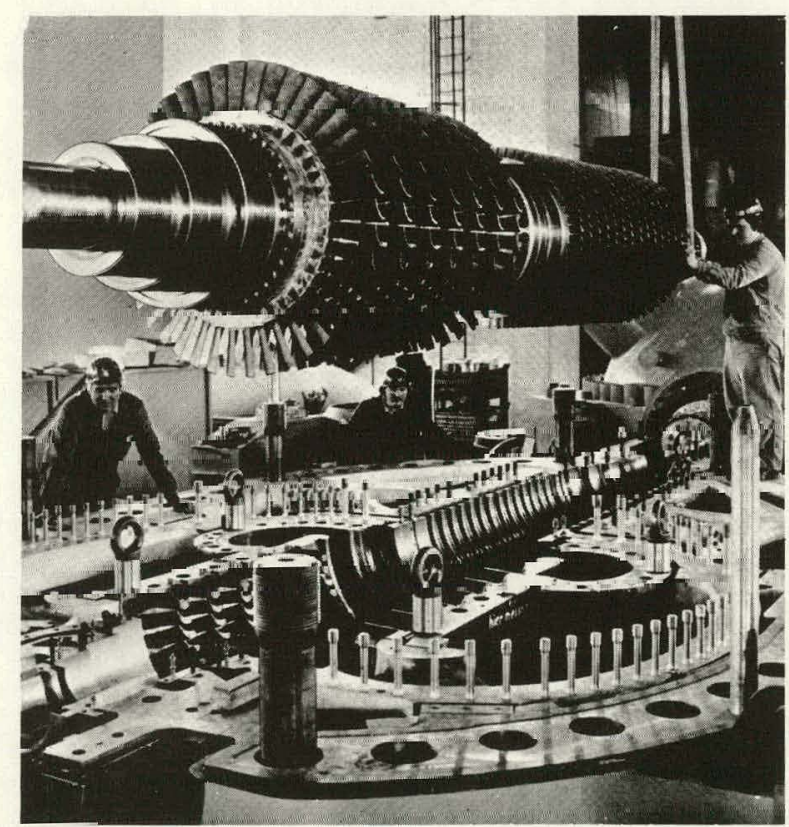

Fig. 3. High-pressure rotor assembly for Oberhausen 2 helium turbine plant (courtesy of Gutehoffnungshütte Sterkrade AG)

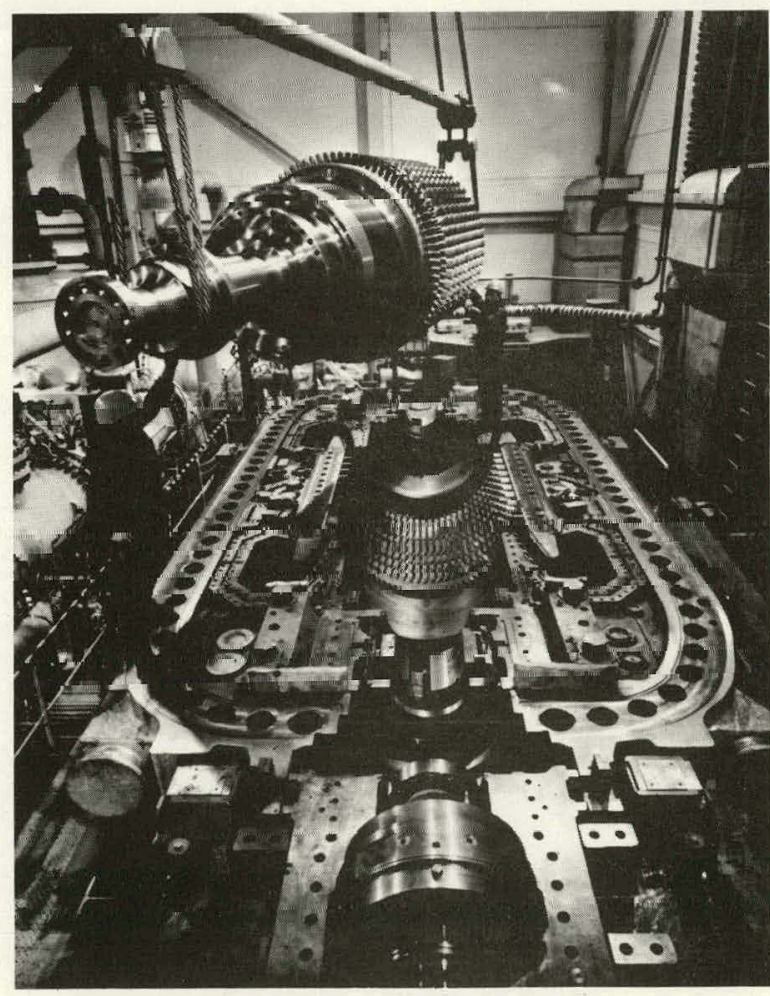

Fig. 4. Helium turbomachine rotor assembly for hightemperature helium test facility (HHV) (courtesy of Brown Roveri. Company) 
U.S.A. . However, it should be mentioned that a formidable effort has also been expended in Europe on the design of the turbomachinery for the HHT Project $(10-13)$ :

\section{HTGR-GI PLANT CONFIGURATION}

Since aspects of the overall plant design are presented in a separate paper for this meeting (1), only a brief description will be given here, with emphasis on the significance of prime-mover integration in the prestressed concrete reactor vessel (PCRV) for turbomachine design. As the plant configuration has evolved from an earlier three-loop reference design (14) to the more recent two-loop arrangement, an integrated approach has been retained. The degree to which the turbomachine is integrated in the PCRV is clearly shown in Fig. 5 .

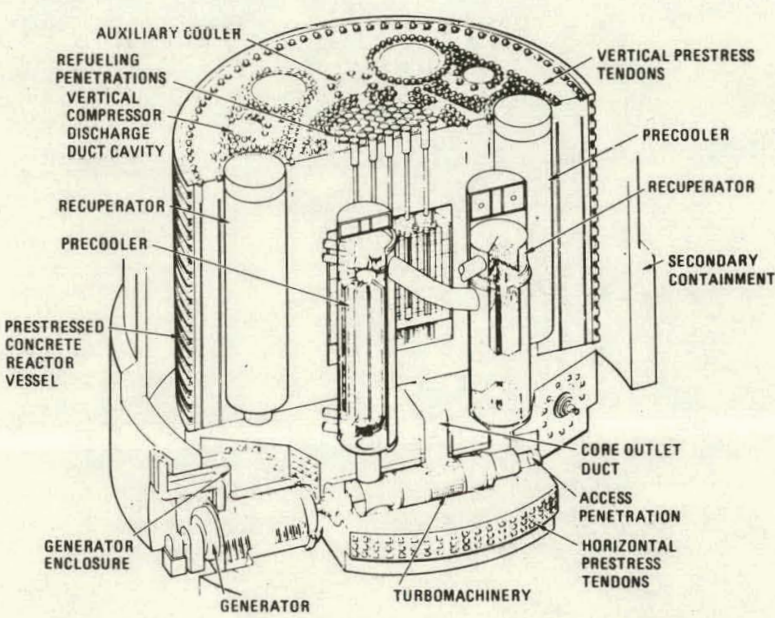

Fig. 5. Isometric view of HTGR-GT power plant primary system showing helium turbomachine integrated in the PCRV

In current studies of a two-loop plant, both intercooled and non-intercooled variants are being evaluatod. However, ful the purposes of this paper, the overall features of the HTGR-GT plant concept can be most simply reviewed by addressing the nonintercooled version. The plan view of the PCRV in Fig. 6 shows the slightly offset core cavity and the two horizontal turbomachine cavities oriented in a chordal manner. The recuperator and precooler are positioned over the turbomachine cavity; and in the case of the intercooled variant, the additional heat exchanger is positioned off to one side of the turbomachine. The elevation view through the PCRV shown in Fig. 7 gives details of the major components in the power conversion loop. An additional elevation view in Fig. 8 shows the hot gas ducl in which the high-temperature helium is transported from the reactor to the turbine.

From these figures it can be seen that the helium turbomachine is truly integrated in the reactor primary system, and thus cannot be designed as an isolated component. In addition to the many mechanical interfaces in the horizontal cavity, the gas flow path directions in and out of the turbomachine play an impnrtant role in the developmeut of the flow path geometries within the entire primary circuit.

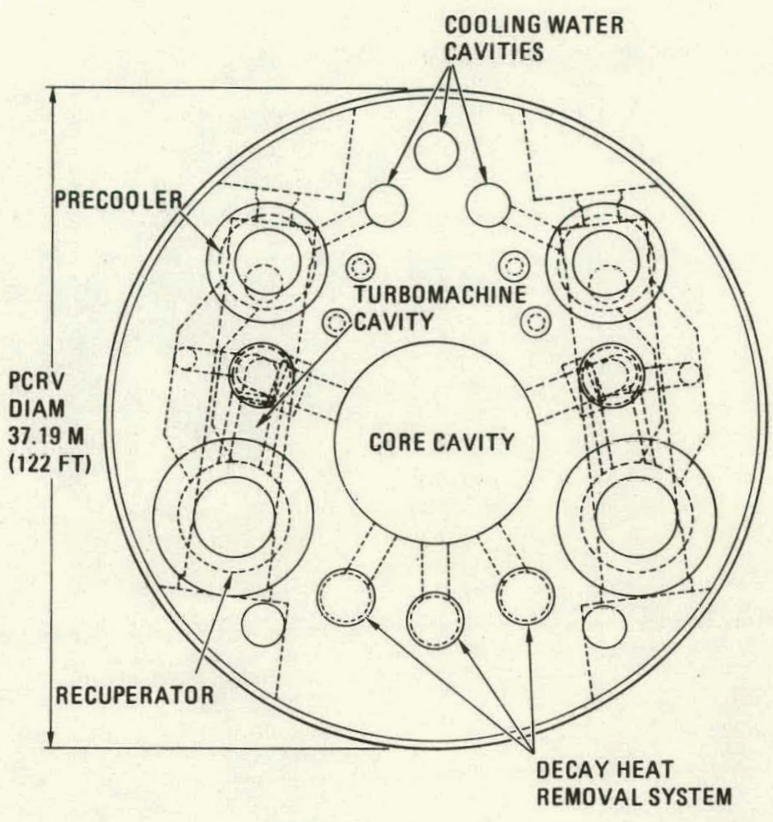

Fig. 6. Plan view of PCRV for two-loop non-intercooled HTGR-GT plant showing orientation of major power conversion system components

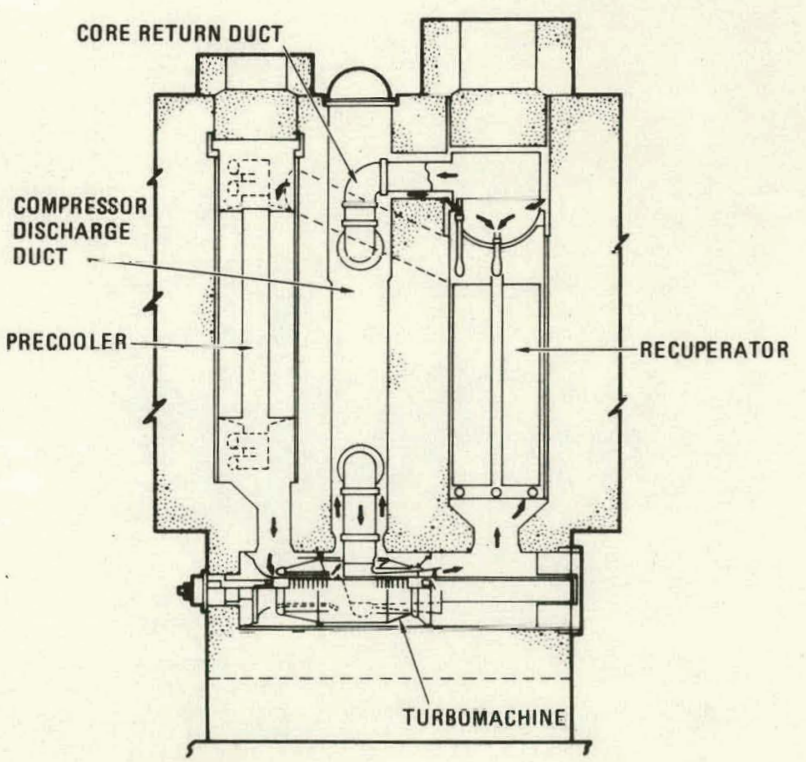

Fig. 7. Elevation view through power conversion loop showing turbomachine and heat exchanger(s) installatiun 


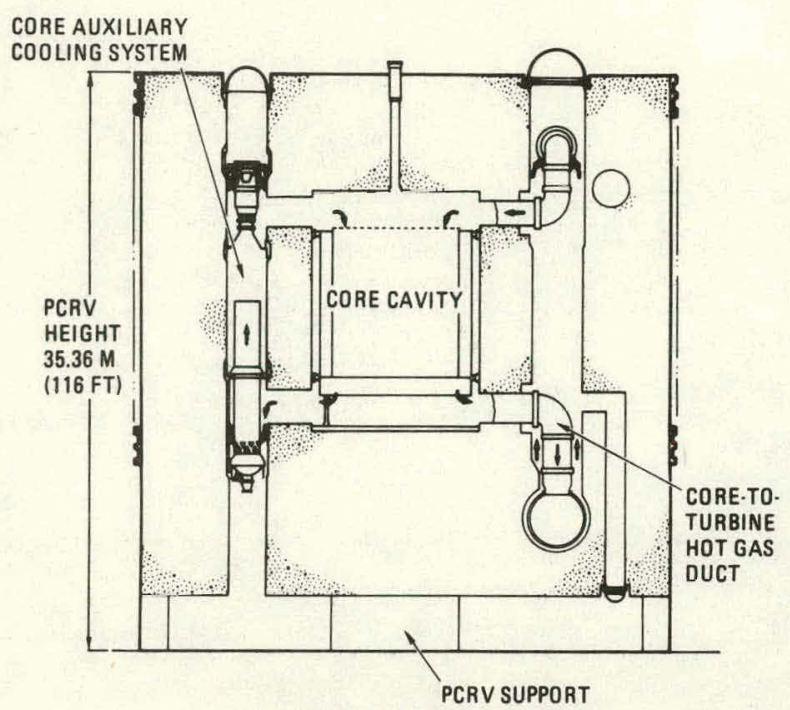

Fig. 8. Elevation view through PGRV showing core cavity and turbine inlet duct

\section{THERMODYNAMIC CYCLE DATA}

As outlined in Ref. 15, studies have been conducted to select cycle parameters (for minimum power generating cost) for both intercooled and nonintercooled plant variants. For the purpose of initiating turbomachine conceptual designs in support of the plant configuration studies, it was necessary to establish comparative cycle data. The tentative values used are shown in Table 1 , and these data are felt to be very representative for turbomachine design purposes. The key differences between the two cycles are shown by the loop diagram for the non-intercooled plant (Fig. 9) and the flow path diagram for the intercooled variant (Fig. 10).

\begin{tabular}{|c|c|c|}
\hline Thermodynamic Cycle & Non-Intercooled & Intercooled \\
\hline Heat Rejection Mode & \multicolumn{2}{|c|}{ Dry-Cooled } \\
\hline Ambient Air Temp., ${ }^{\circ} \mathrm{C}\left({ }^{\circ} \mathrm{F}\right)$ & \multicolumn{2}{|c|}{$15(59)$} \\
\hline Recuperator Ef fect iveness & 0.90 & 0.90 \\
\hline $\begin{array}{l}\text { Approx. System Pressure Loss } \\
(\triangle \mathrm{P} / \mathrm{P}), \%\end{array}$ & 9 & 11 \\
\hline Compressor Flow, $\mathrm{kg} / \mathrm{s} / \mathrm{MW}(\mathrm{t})$ & 0.57 & 0.50 \\
\hline Compressor Inlet Temp., ${ }^{\circ} \mathrm{C}\left({ }^{\circ} \mathrm{P}\right)$ & $26.7(80)$ & $26.7(80)$ \\
\hline $\begin{array}{l}\text { Compressor Inlet Pressure, } \\
\text { MPa (paia) }\end{array}$ & $3.17(460)$ & $2.64(383) / 4.5(653)$ \\
\hline Compressor Pressure Rat io & 2.50 & $3.0(1.73 / 1.73)$ \\
\hline Compressor Efficiency, $\%$ & 89.8 & $90.8 \mathrm{LP}, 90.2 \mathrm{HP}$ \\
\hline Turbine Inlet Temp., ${ }^{\circ} \mathrm{C}\left({ }^{\circ} \mathrm{F}\right)$ & $850(1562)$ & $850(1562)$ \\
\hline $\begin{array}{l}\text { Turbine Inlet Pressure, } \\
\text { MPa (pola) }\end{array}$ & $7.65(1109)$ & $7.56\left(1090^{\circ}\right)$ \\
\hline Turbine Expansion Ratio & 2.34 & 2.74 \\
\hline Turbine Efficiency, \% & 91.8 & 92.2 \\
\hline Tutbine cooling Flow, \%* & 3.6 & 3.6 \\
\hline $\begin{array}{l}\text { Precooler water Outlet Temp., } \\
{ }^{\circ} \mathrm{C}\left({ }^{\circ} \mathrm{F}\right)\end{array}$ & $132(270)$ & $87(189)$ \\
\hline $\begin{array}{l}\text { Intercuoler Warer out let Temp., } \\
{ }^{\circ} \mathrm{C}\left({ }^{\circ} \mathrm{F}\right)\end{array}$ & --- & $66(150)$ \\
\hline Approx. Cycle Ffficiency, \% & 40.0 & 42.0 \\
\hline
\end{tabular}

*The designs of both machines are based on utilization of uncooled turbine blades, and the cooling flows indicated (as a percentage of compressor discharge flow) are necessary for cooling the turbine rotor, structures, and casing to satisfy the 280, ann-hr life reyuliemelll.

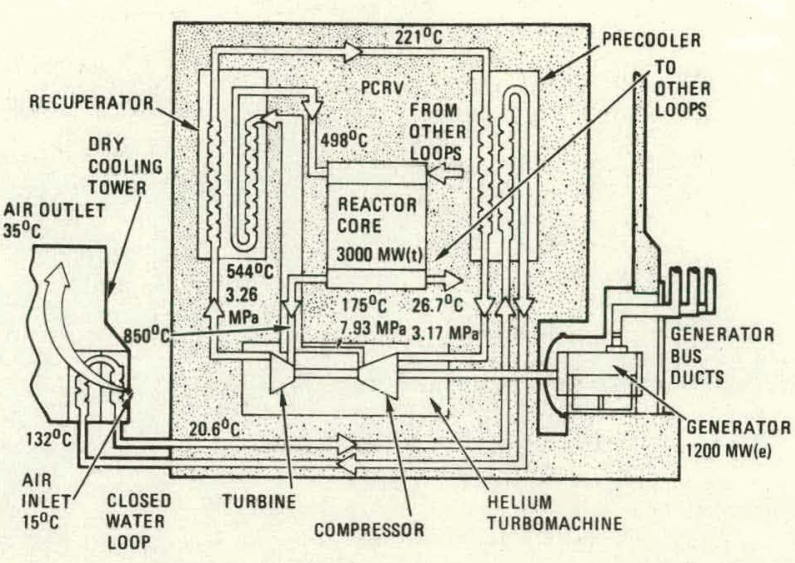

Fig. 9. Loop cycle diagram for non-intercooled drycooled HTGR-GT power plant

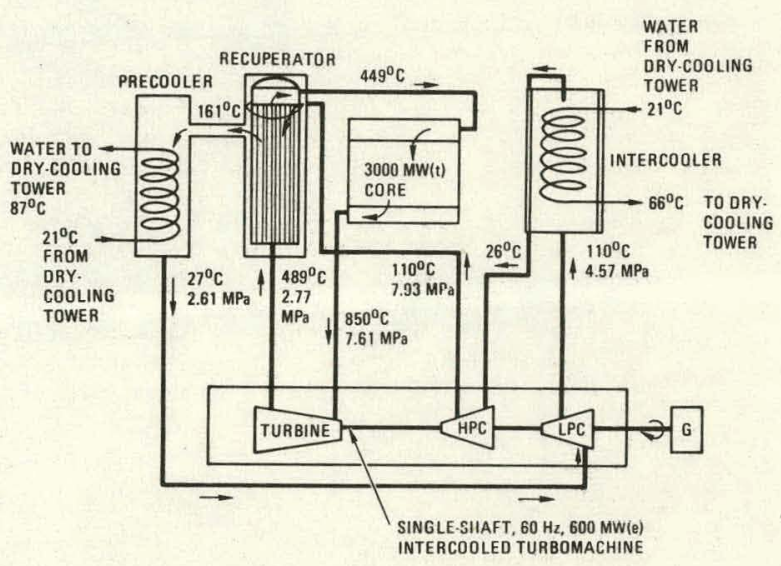

Fig. 10. Flow path diagram for intercooled HTGR-GT power plant

From Table 1 it can be seen that the optimized value of the compressor pressure ratio for the intercooled variant is a little higher than that for the non-intercooled cycle, and this results in an increased specific power. The maximum system pressure of $7.93 \mathrm{MPa}$ ( $1150 \mathrm{psia}$ ) is the same for both cycles and is related strongly to cost of the PCRV. An important parameter influencing cycle efficiency is the turbine inlet temperature, and for both cycles a value of $850^{\circ} \mathrm{C}\left(1562^{\circ} \mathrm{F}\right)$ was assumed. As shown in Fig. 11, this temperature is modest compared with that for most industrial gas turbines. It is below the level where turbine blade cuuling is necessary, and it facilitates utilization of an existing nickel-base alloy which is used extensively in industrial gas turbines.

\section{TURBOMACHINE GAS DYNAMIC DESIGN CONSIDERATIONS}

For both the non-intercooled and intercooled machines, simple and rugged arrangements consisting of single-shaft, twn-hearing, direct-drlve turbomachine arrangements were chosen for the HTGR-GT 
plant. Simplified cross sections of the 400-MW(e) non-intercooled and 600-MW(e) Intercooled machines are shown in F1gs. 12 and 13, respectively, and design detalls are given in Table 2.

For an integrated plant arrangement with a Iimitation on machine envelope, close cooperation between the turbomachinery and primary system designers is essential. Since high turbomachinery efficiencies are required, it is important that minimum loss ducts to and from the compressor and turbine be incorporated, which necessitates close attention to the interfacing of the gas turbine with the other components in the power conversion loop. Minimum loss ducts with carefully contoured geometries to give good flow distribution into the compressor and turbine tend to require large volutes and scrolls. However, with the installation of the machine in the horizontal cavity in the PCRV and the requirement for minimizing the bearing span to give satisfactory rotor dynamic characteristics (i.e., critical speed margin), large flow areas are not available (as can be seen in Figs. 12 and 13), and trade-offs are necessary to satisfy both aerodynamic and structural requirements for the selected primary system. Gas dynamic design considerations for the compressor and turbine are briefly discussed below.

\section{Compressor Gas Dynamic Design Consideration}

Since axial compressor aerothermodynamic design techniques have been well documented, detalled analyses will not be described herein. The purpose of this paper is instead to outline how the fluid properties of helium influence the flow path geometries and to emphasize that the gas dynamic procedures used are essentially identical to cunventional airbreathing gas turbine practice.

The choice of working fluid affects the turbomachine primarily in two ways: (1) the number of stages for the attainment of the required compressor pressure ratio and high efficiency, and (2) the machine size for a high-pressure closed-cycle system. The specific heat of helium is five times that of air, and since the stage temperature rise varies inversely to the specific heat (for a given limiting blade speed), it follows that the temperature rise available per stage when running with helium will be only one fifth that of air, and this of course results in more stages being required for a helium compressor. It is fortunate that the optimization (for maximum cycle efficienry) of a highly recupesaled closed-cycle system gives a relatively low pressure ratio, because the number of compressor stages ( 18 and 16 for the non-intercooled and intercooled variants, respectively, as can be seen from Table 2) is therefore comparable to existing open-cycle industrial gas turbines.

Substitution of helium for air greatly modifies aerodynamic requirements by removing Mach number limitations. The problem then becomes trying to induce the highest possible gas velnrities that atress limited blades will allow. For the selected singleshaft arrangements outlined in Table 2 , the compressor rotational speed is, of course, fixed at the generator synchronous speed of $3600 \mathrm{rpm}$ for a $60-\mathrm{Hz}$ machine. The size of the machine is thus dictated by the choice of blade speed, there being an incentive to use the highest values possible commensurate with stress limits to reduce the number of stages, since the stage loading factor is inversely proportional to the square of the blade speed.

For the specified thermodynamic conditions, detailed gas dynamic analyses were performed by

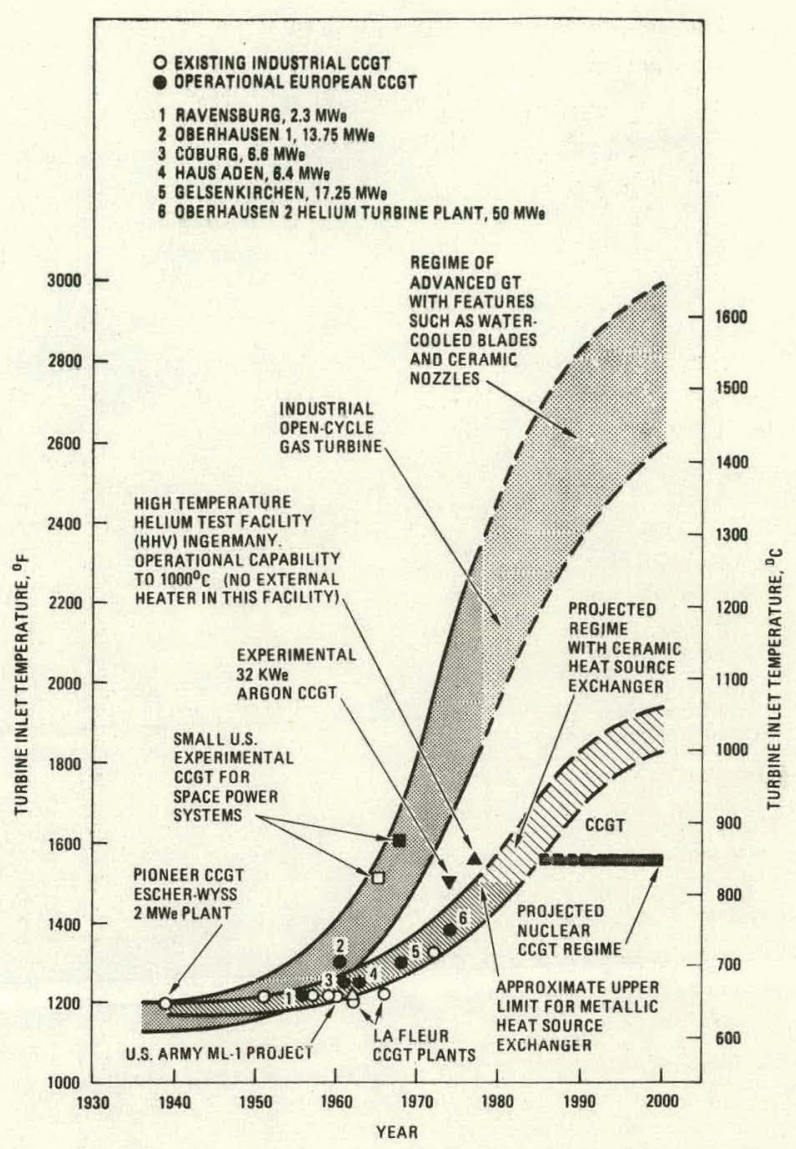

Fig. 11. Turbine inlet temperature trends for closedcycle and open-cycle industrial gas turbines

TABLE

DETAILS OF HTGR-GT PLANT TURBOMACHINE DESIFNS

\begin{tabular}{|c|c|c|}
\hline Turbomachine Rating, MW(e) & 400 & 600 \\
\hline Maclitue Type & Non-Intercooled & Intercooled \\
\hline $\begin{array}{l}\text { Machine Arrangement } \\
\text { Frequency, } \mathrm{Hz}\end{array}$ & $\begin{array}{l}\text { Single-Shaft } \\
60\end{array}$ & $\begin{array}{l}\text { Single-Shaft } \\
60\end{array}$ \\
\hline No. of Turbine Inlet Ducts & $\begin{array}{r}00 \\
1\end{array}$ & $\begin{array}{r}60 \\
1\end{array}$ \\
\hline Turbine inlet Temp., ${ }^{\circ} \mathrm{C}\left({ }^{\circ} \mathrm{F}\right)$ & $850(1562)$ & $850(1562)$ \\
\hline Compressor Pressure Ratio & 2.50 & $3.0(1.73 / 1.73)$ \\
\hline No. of Compressor Stages & $1.83^{18}(71.9)$ & \\
\hline $\begin{array}{l}\text { Max. Compressut Tip Dia., } \\
\text { m (in.) }\end{array}$ & $1.83(71.9)$ & $2.18(85.9)$ \\
\hline $\begin{array}{l}\text { Blade Height, mm (in.) } \\
\text { (min./max.) }\end{array}$ & $\begin{array}{l}80.0 / 125.7 \\
(3.1 / 4.9)\end{array}$ & $\begin{array}{c}76.2 / 165.1 \\
(3 / 6.5)\end{array}$ \\
\hline $\begin{array}{l}\text { Comp. Adiabatic Efficiency } \\
\text { (across blading), } \%\end{array}$ & 89.8 & $90.8 \mathrm{LP} / 90.2 \mathrm{HP}$ \\
\hline No. of Turbine Stages & 8 & 9 \\
\hline Max. Tutbine lip Via., m (in.) & $2.18(86)$ & $2.40(94.5)$ \\
\hline $\begin{array}{l}\text { Blade Height, mm (in.) } \\
\text { (min./max.) }\end{array}$ & $\begin{array}{l}125.7 / 297.2 \\
(4.9 / 11.7)\end{array}$ & $\begin{array}{l}165.1 / 393.7 \\
(6.5 / 15.5)\end{array}$ \\
\hline $\begin{array}{l}\text { Turbine Isentropic Efficiency } \\
\text { (acrose blading), }\end{array}$ & 91.8 & $9 ? .2$ \\
\hline Blading Life, hr & 280,000 & 280,000 \\
\hline Blade Cooling & No & \\
\hline $\begin{array}{l}\text { Turbine Blade Material } \\
\text { Gienerator Drive End }\end{array}$ & \multicolumn{2}{|c|}{$\begin{array}{l}\text { Nickel-Base Alloy, } \quad \mathrm{N}-100 \\
\text { Compressor }\end{array}$} \\
\hline Rotor Burst Shield & \multicolumn{2}{|c|}{ Yes, Integral Part of Machine Structure } \\
\hline $\begin{array}{l}\text { Thrust Bearing Position } \\
\text { No. of Journal Bearings }\end{array}$ & Externa & to PCRV \\
\hline Journal Bearing Man Access & Yes & Yes \\
\hline Type of Rotor Construction & Welded Rotor & Welded Rotor \\
\hline Mach ine Casing Diameter, in $(\mathrm{ft})$ & $4.0(13.1)$ & $4.0(13.1)$ \\
\hline Machine Length, $m(\mathrm{ft})$ & $11.3(37)$ & $15.8(52)$ \\
\hline Machine Weight, $\mathrm{kg}$ (ton) & \multirow{2}{*}{\multicolumn{2}{|c|}{ l.arge Industrial open-Cyclo cias Turbines }} \\
\hline Design Tecnnology Base & & \\
\hline
\end{tabular}




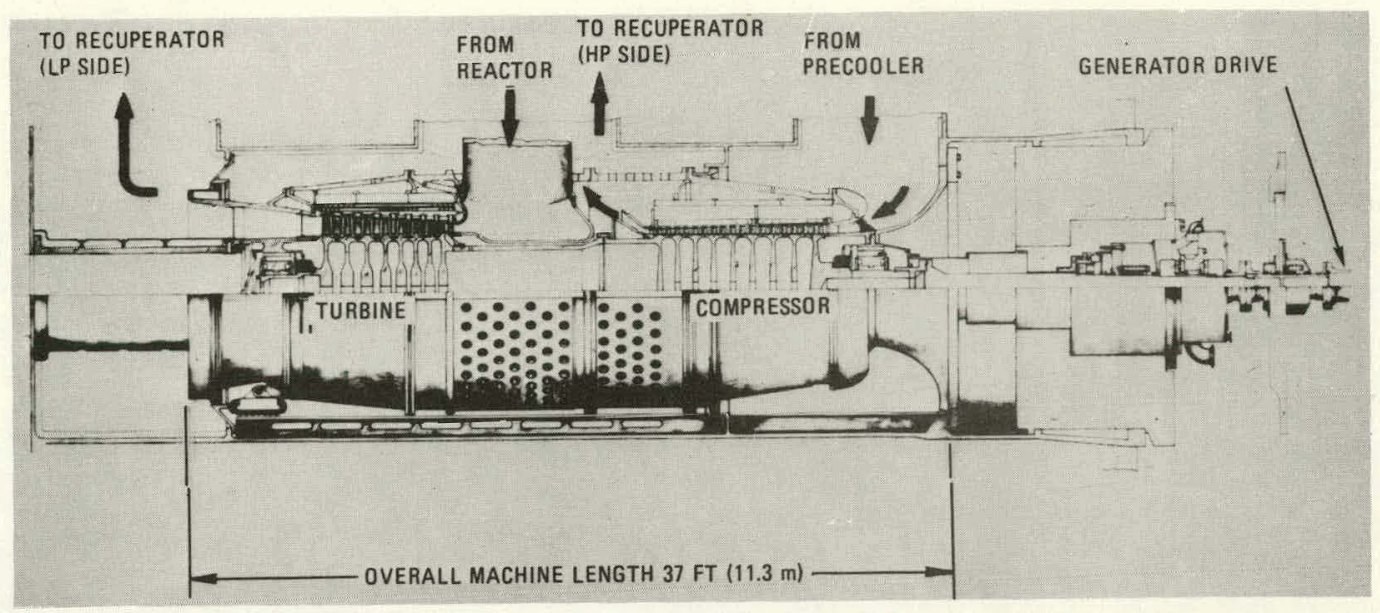

Fig. 12. Arrangement of 400-MW(e) non-intercooled turbomachine for HTGR-GT plant

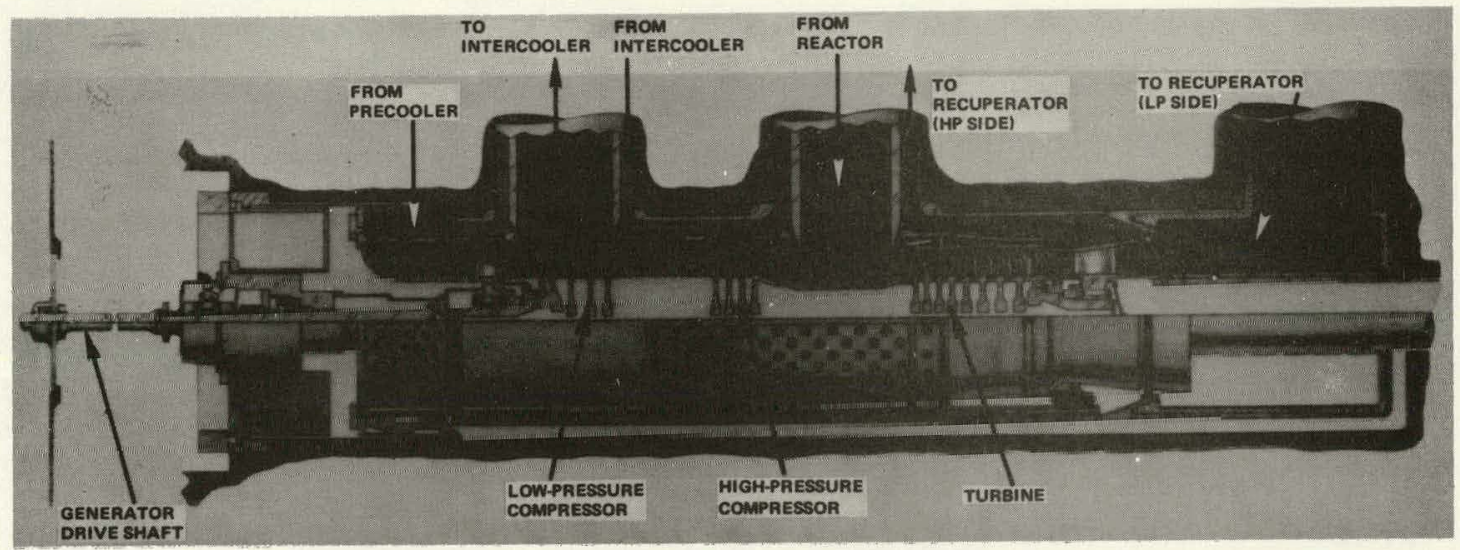

Fig. 13. Arrangement of 600-MW(e) intercooled turbomachine for HTGR-GT plant

United Technologies Corporation (UTC) to identify optimum solutions for the HTGR-GT turbomachine. Details of the selected compressor dcsigns are given in Table 2. Helium compressors for closedcycle gas turhines are characterized by sull blade heights, high hub-to-tip ratios, and low aspect ratios. An important parameter is the rear stage hub-tn-tip ratio, and an accepled upper limit for high efficiency compressors is about 0.90. With high-pressure helium, the blade heights are small and end-wall losses become significant; thus, careful mechanical design is necessary to minimize tip clearance effects. While the end-wall effects have an adverse effect on efficiency, two factors that will partially offset this are the very high Reynolds numbers $\left(6 \times 10^{6}\right)$ and the very low Mach number $(0.40)$. The high-efficiency design solutions given in Table 2 have acceptable gas dynamic loading tactors characteristic of conservatively designed industrial gas turbines and should give a satisfactory surge margin.

Turbine Gas Dynamic Design Considerations

The properties of helium affect the turbine in very much the same way that they influence the compressor. That is, for a given overall expansion ratio, the total number of stages for a helium turbine will be much greater than for an air-breathing gas turbine. Because it is desirable to have as high a blade speed as possible in order to reduco the number of stages to a minimum, the most critical stress conditions are those of the first stage since the rotor blade temperature is at the maximum value. The turbine blade centrifugal stress (for a given blade geometry) is proportional to $\mathrm{rpm}^{2} \mathrm{x}$ annulus area, and for a single-shaft, $60-\mathrm{Hz}$ machine, one degree of freedom is lost to the designer. A conservative ground rule established for the HTGR-GT plant is that the stress levels in the primary system components must be commensurate with the plant uperating life of $280,000 \mathrm{hr}$ (i.e., $40 \mathrm{yr}$ with a capacity factor of $80 \%$ ). The preliminary turbine designs [with a gas inlet temperature of $850^{\circ} \mathrm{C}$

$\left.\left(1562^{\circ} \mathrm{F}\right)\right]$ performed by United Technologies Corporation and outlined in this paper have been based on the use of an existing turbine blade nickel-base alloy that has been used extensively in open-cycle industrial gas turbines. The use of advanced materials (molybdenum alloys, for example) or blade cooling may be desirable at some time in the future when reactor outlet temperatures are increased above present-day values. 
From Table 2 it can be seen that eight- and nine-stage turbine designs were selected for the non-intercooled and intercooled plant variants, respectively. With tip speeds conservative by modern industrial turbine practice, it can be seen that helium turbines are characterized by small blade heights. In fact, the turbine is substantially smaller than an equivalent air-breathing turbine since the enthalpy drop in the helium turbine is many times greater (i.e., very high specific power).

\section{Turbomachinery Performance Predictions}

The performance predictions for the helium turbomachines discussed in this paper are based on established design methodology, and the high compressor and turbine efficiency values given in Table 2 reflect the influence of technology from a demonstrated advanced-technology industrial gas turbine [UTC 100-MW(e) FT-50 engine] as described in Refs. 16 and 17 . The closed-cycle gas turbine plant is sensitive to small changes in compressor and turbine efficiencies as can be seen in Fig. 14, which illustrates performance data for the non-intercooled cycle.

Since the design of the helium turbomachinery for the HTGR-GT plant draws heavily on established industrial gas turbine practice, it is germane to compare design parameters. In Table 3 , the salient features of the HTGR-GT turbomachine are compared with the FT-50 100-MW(e) industrial gas turbine. The flow path geometries and gas dynamic features of these two machines are compared in Fig. 15. Mechanical design comparisons are discussed in the following section.

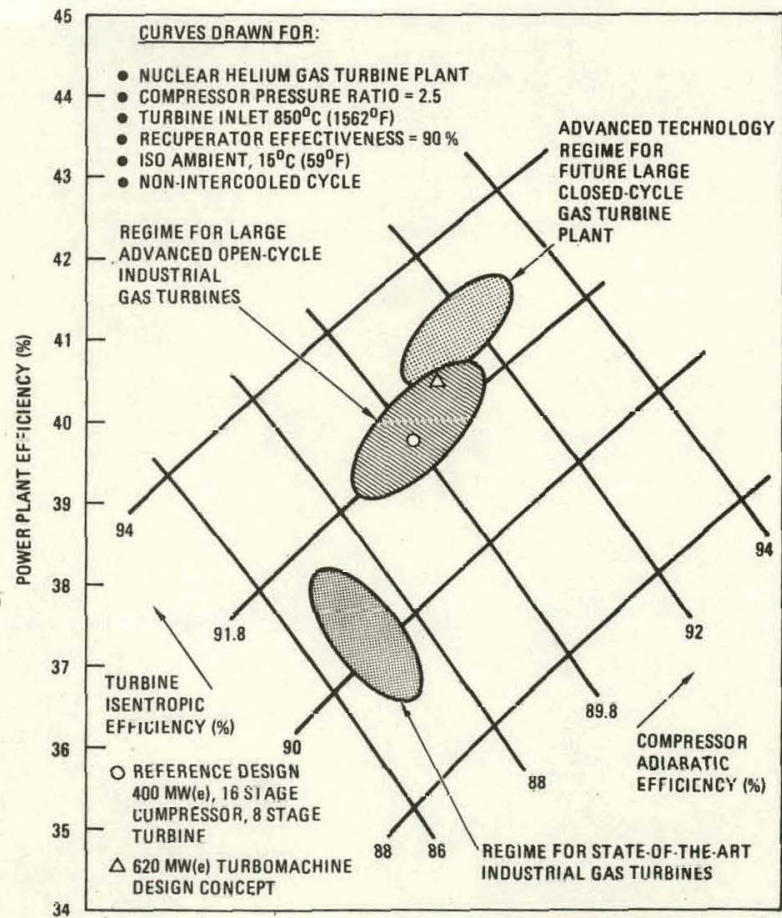

Fig. 14. Array showing influence of compressor and turbine efficiencies on performance of nonintercooled HTGR-GT power plant
TABLE 3
HTGR-GT - INDUSTRIAL GAS TURBINE COMPARISON

\begin{tabular}{|c|c|c|c|}
\hline $\begin{array}{l}\text { Application } \\
\text { Power Plant }\end{array}$ & \multicolumn{2}{|c|}{$\begin{array}{l}\text { Nuclear Closed-Cycle } \\
\text { Gas Turbine }\end{array}$} & $\begin{array}{c}\text { Industrial } \\
\text { Open-Cycle } \\
\text { Gas Turbine } \\
\text { FT-50 }\end{array}$ \\
\hline $\begin{array}{l}\text { Turbomachine Status } \\
\text { Turbomachine Type }\end{array}$ & \multicolumn{2}{|c|}{$\begin{array}{c}\text { Conceptual Design } \\
\text { Single-Shaft }\end{array}$} & $\begin{array}{l}\text { Operational } \\
\text { Split Shaft } \\
\end{array}$ \\
\hline Power Output, MW(e) & \begin{tabular}{c|}
400 \\
Non-Intercooled
\end{tabular} & \begin{tabular}{|c|}
600 \\
Intercooled
\end{tabular} & 100 Non-Intercooled \\
\hline $\begin{array}{l}\text { Working Fluid } \\
\text { Rotational Speed, rpm }\end{array}$ & $\begin{array}{l}\text { Helium } \\
3600\end{array}$ & $\begin{array}{l}\text { Helium } \\
3600\end{array}$ & $\begin{array}{l}\text { Air } \\
\text { LP Compressor } 3520 \\
\text { HP Compressor } 4200 \\
\text { Power Turbine } 3600\end{array}$ \\
\hline Turbine Inlet Temp., ${ }^{\circ} \mathrm{C}\left({ }^{\circ} \mathrm{F}\right)$ & 850 (1562) & $850(1562)$ & $\begin{array}{l}\text { Power Turbine } 3600 \\
1121(2050)\end{array}$ \\
\hline Turhine Blade Temp., "C ( $\left.{ }^{\circ} \mathrm{F}\right)$ & $816(1500)$ & 816 (1500) & $816(1500)$ \\
\hline Compressor Pressure Rat io & 2.50 & 3.0 & 16.0 \\
\hline No. of Compressor Stages & 18 & $8+8$ & 17 \\
\hline No. of Turbine Stages & & & 4 \\
\hline $\begin{array}{l}\text { Max, Compressor Disk Dia., } \\
\min (\text { in.) }\end{array}$ & $1575(62)$ & $1854(73)$ & $1321(52)$ \\
\hline $\begin{array}{l}\text { Max. Turbine Disk Dia., } \\
\text { mm (in.) }\end{array}$ & $1600(63)$ & $1600(63)$ & $1575(62)$ \\
\hline Max, Blade Height, $\operatorname{mos}($ in.) & $297(11.7)$ & $394(15.5)$ & $635(25)$ \\
\hline $\begin{array}{l}\text { Max, Turbine Tip Speed, } \\
\mathrm{m} / \mathrm{s}(\mathrm{ft} / \mathrm{sec})\end{array}$ & $412(1350)$ & $453(1485)$ & $536(1760)$ \\
\hline $\begin{array}{l}\text { Max. Journal Bearing Dia., } \\
\min (\text { in.) }\end{array}$ & $508(20)$ & $600(24)$ & 381 (15) \\
\hline $\begin{array}{l}\text { Max. Engine Dia., In }(\mathrm{ft}) \\
\text { Overa11 Length. }\end{array}$ & $4.0(13.1)$ & $\begin{array}{r}4.0(13.1) \\
15.8(52)\end{array}$ & $\begin{aligned} 3.2(10.5) & \end{aligned}$ \\
\hline $\begin{array}{l}\text { Overall Length, } m \text { (ft) } \\
\text { Assembly Weight, } k g \text { (ton) }\end{array}$ & $\begin{aligned} 11.3 & (37) \\
276,770 & (305)\end{aligned}$ & $\begin{array}{c}15,8(52) \\
317,600(350)\end{array}$ & $\begin{aligned} 11.6 & (38) \\
113,430 & (125)\end{aligned}$ \\
\hline
\end{tabular}

\section{TURBOMACHINE MECHANICAL DESIGN CONSIDERATION}

Design criteria unique to the nuclear application had a strong influence on the overall design of the helium turbomachine, and the two variants shown in Figs. 12 and 13 are similar enough in overall construction to be addressed together as follows. Because the machine will become contaminated in service, the overall design of the casings and structures must be such that remote handling, decontamination, and maintenance procedures are applicable to such conditions. On first consideration, it would appear that these requirements could be satisfied with an arrangement having a full-length split casing design. For such a configuration (as shown in Figs. 3 and 4, for example), the casings could be separated and the rotor removed as a single unit. However, an important element in the design of the turbomachine is the incorporation of containment rings around the rotor bladed sections to contain fragments and missiles in the unlikely event of a rotor failure. Use of a full-length split casing design would require incorporation of split containment rings, which, as will be discussed below, are uul fele to be viable.

As shown in Figs. 12 and 13, the turbomachine casings are of the double-wall type in which the stator blades of the turbine and compressor are supported on an inner high-temperature-resistant casing and the alignment between the bearing housing and the high-temperature casing is maintained by the cooled outer casing. The overall structure can be appreciated by studying Fig. 16, which shows the separation sequence for a candidate intercooled machine. The way in which the casiugs are split satisfies the aforementioned requirements of (1) remote disassembly capability and (2) full circumferential containment rings. Key clements of the helium turbomachine mechanical design are discussed below.

\section{Turbomachine Rotor}

A simple two-bearing arrangement was selected for the turbomachine rotor, and man access cavities have been provided in the PCRV for inspection of and limited work on the journal bearings. Detailed rotor dynamic analyses have confirmed the adequacy of the two-bearing arrangement, aud satisfactory critical 


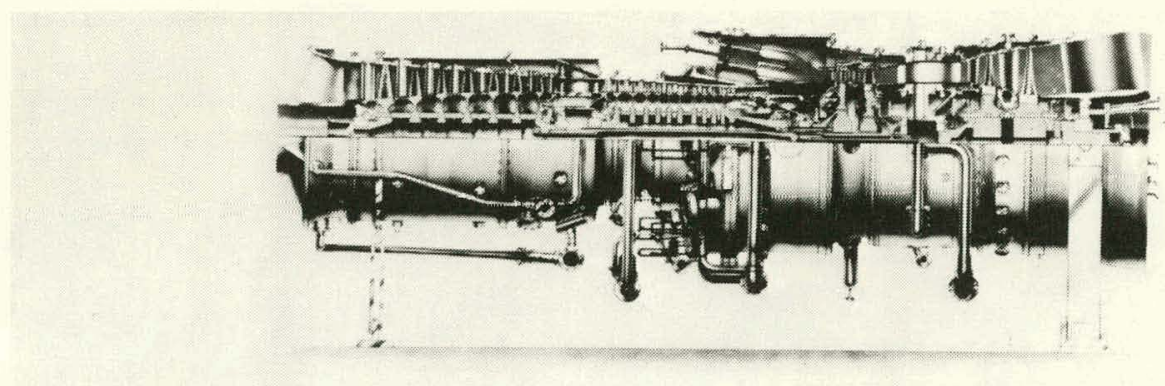

100 MWE UNITED TECHNOLOGIES FT50 ADVANCED OPEN-CYCLE INDUSTRIAL GAS TURBINE
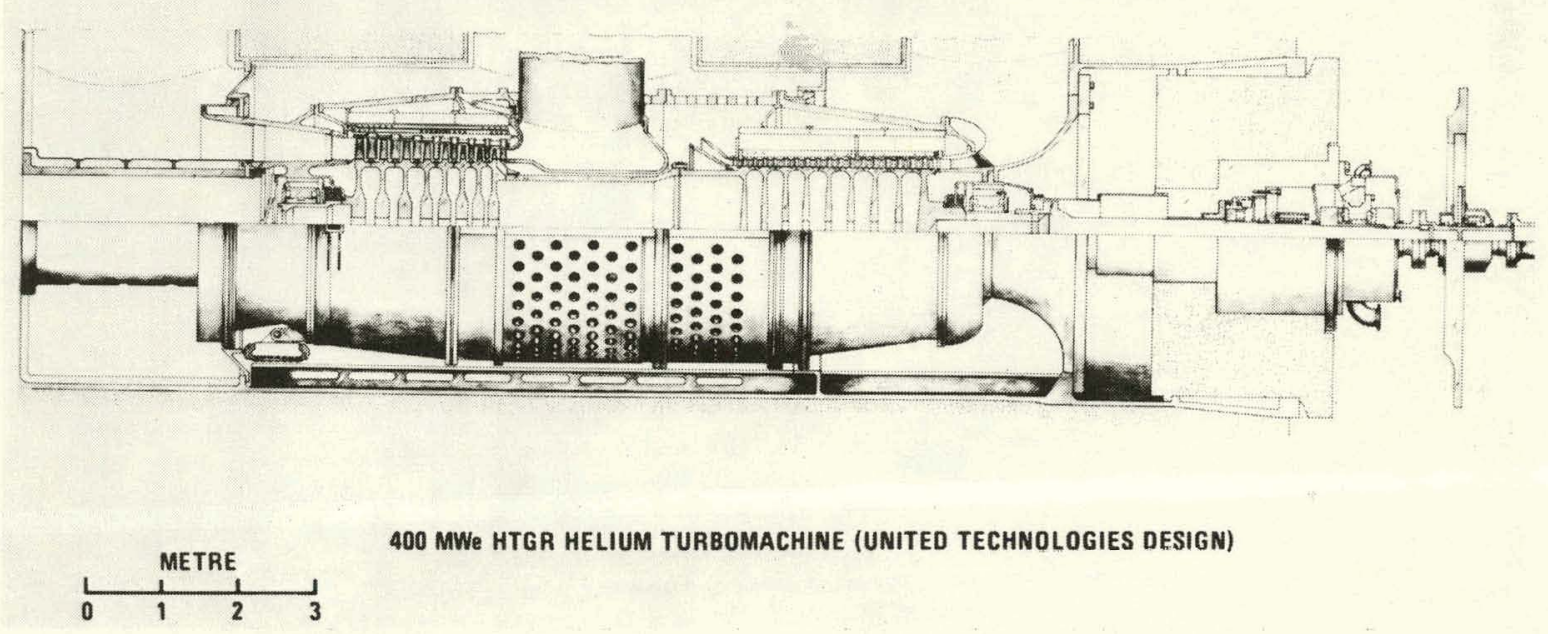

400 MWe HTGR HELIUM TURBOMACHINE (UNITED TECHNOLOGIES DESIGN)

Fig. 15. Comparative sizes of open- and closed-cycle turbomachines

speed margins have been identified for the overspeed condition.

The rotor is of welded construction. Welded rotors have a long successful history in Europe. The view of the compressor rotor (for the non-intercooled machine) in Fig. 17 shows the welded disk construction, the tangential blade attachments, and the dual blade rows mounted on parh disk. This lesign minimizes weight, machining time, and number of parts compared with more traditional bolted-up rotor assemblies. The turbine design shown in Fig. 18 also employs the welded rotor concept. It has an insulated case to reduce materials cost and give tip clearance control. Tangential blade attachments are used to minimize turbine secondary cooling requirements and improve performance. Unlike fossil-fired open-cycle gas turbines (aircraft and industrial), low cycle fatigue and hot corrosion are not design fartors with this rulus. However, creep rupture and high cycle fatigue are design considerations. For the turbine blading, creep is the life-limiling factor. Tn the case of the turbine disks, fracture mechanics are the controlling design criteria. A total bleed flow from the compressor of $3.6 \%$ of the total flow is required for cooling the hot-end structures. The turbine casing requires $0.6 \%$ of the flow, and $3.0 \%$ is distributed in the turbine welded rotor assembly to give an average disk temperature of $315^{\circ} \mathrm{C}\left(600^{\circ} \mathrm{F}\right)$. For the turbine blading (uncooled), the stress level is well within the limits for $1 \%$ creep of the nickel-base alloy IN-10n at $280,000 \mathrm{hr}$, which is the design life of the blading. Aircraft and industrial gas turbines are designed so that in the event of a blade failure, the fragments are contained within the machine casings. However, the casings of these machines are not designed for containment of a failed sulus for reasons of weight limitation for the aircraft application and because of economic considerations in the case of industrial applications. This design practice has proved to be sound since rotor failures in modern gas turbines are rare events.

For the HTGR-GT plant, with the turbomachine installed inside the reactor vessel, it was felt not only to be prudent but in fact a safety requirement that fragments and missiles generated in the unlikely event of a rotor failure would be rnntained within the turbomachine casing. As mentioned previously, rotor burst protection is incorporated in the machine design in the form of cuntainment rings (sometimes referred to as burst or missile shields) around the compressor and turbine rotor bladed sections (18). The procedure outlined in Ref. 19 was used to analyze the mechanics of containment of the eighth-stage disk in the 400-MW(e) helium turbomachine at the minimum burst speed condition, which for this machine is $150 \%$ of the $3600-\mathrm{rpm}$ operating speed. The analysis showed that a containment ring of 178-mm (7-in.) thickness should be adequate to contain an eighth- 


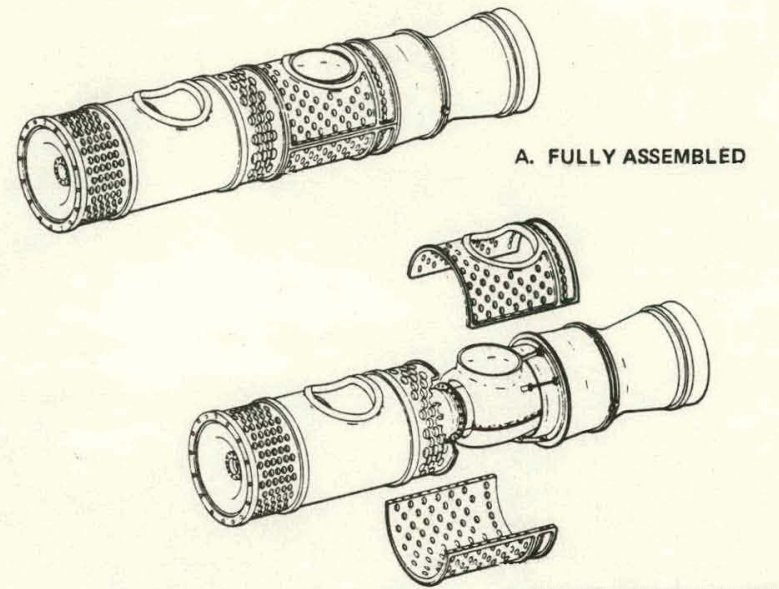

B. SPLIT CASES SEPARATED

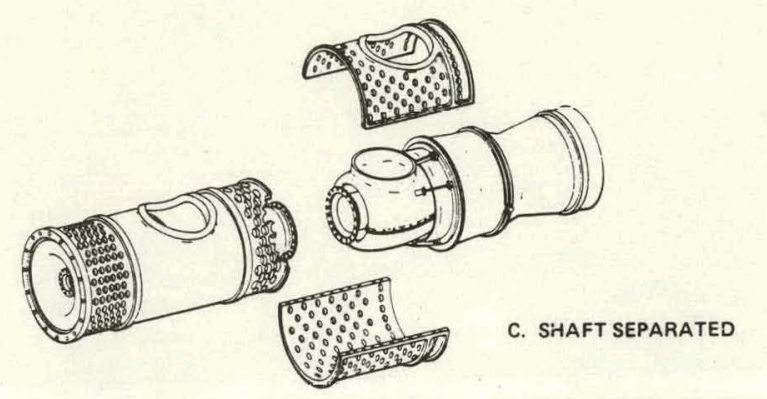

Fig. 16. Example of assembly separation sequence for HTGR-GT plant helfum turbomachine

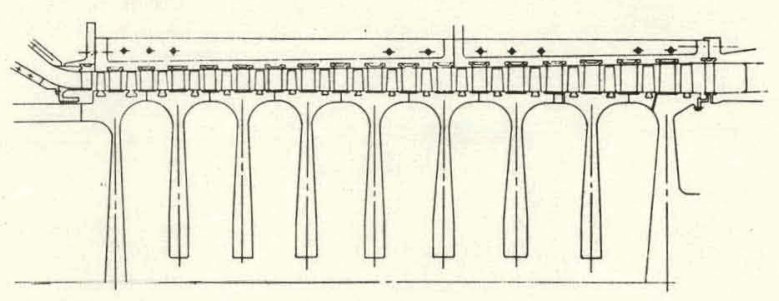

Fig. 17. View of welded compressor rotor assembly for non-intercooled HTGR-GT turbomachine

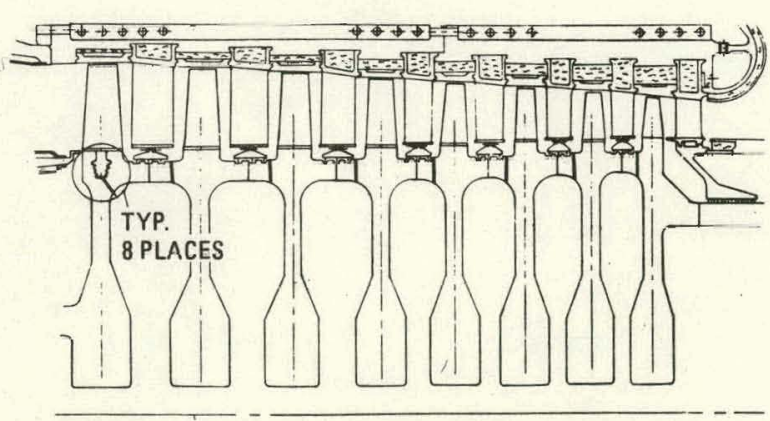

Fig. 18. View of welded turbine rotor assembly for HTGR-CT turbomachine stage disk failure. The nature of the energy absorption process, which depends upon large plastic strain in the containment ring, precludes the use of any sort of axial mechanical joints in the ring and, as mentioned earlier, negates the use of a fulllength horizontally split casing configuration.

Bearings

Oil-1ubricated journal bearings were chosen since, in general, minimum film thicknesses for oil bearings were found to be about twice as great as those for water bearings with the same length/ diameter ratio, and maximum allowable misalignments were found to be more flexible than for water bearings. Similarly, gas and magnetic bearings were not considered feasible for such large systems with rotor weights in excess of $60,000 \mathrm{~kg}$ ( 66 tons). The journal bearings are subjected to high radial loading during normal operation and must be capable of withstanding temporary overload due to a seismic event. Tilting pad bearings were selected because of their self-aligning stability. Details of the journal bearings for the 400-MW(e) machine are shown in Fig. 19. The bearings are five-pad tilting pad designs with a shaft journal diameter of $508 \mathrm{~mm}$ ( $20 \mathrm{in.)}$ and a length of $406 \mathrm{~mm}$ (16 in.). For the $600-\mathrm{MW}(\mathrm{e})$ machine, the diameter is $600 \mathrm{~mm}$ (24 in.), compared with $381 \mathrm{~mm}$ (15 in.) for a 100-MW(e) opencycle industrial gas turbine (Table 3 ). The pads are supported on pivots offset from the pad center in the direction of rotation to enhance the self-actuation of the pads (see Fig. 19). Man access cavities are provided in the PCRV for inspection of and limited maintenance work on the journal bearings. The spaces in which the bcarings are located are isolated from the main cycle working fluid by shielding (purge gas from the helium purification system is used to give an acceptable radiological environment for man access).

Integrating the turbomachine in the PCRV creates some unique requirements for the thrust bearing. The high pressure level at which the plant operates produces very high individual forces in various parts of the turbomachine rotor assembly.

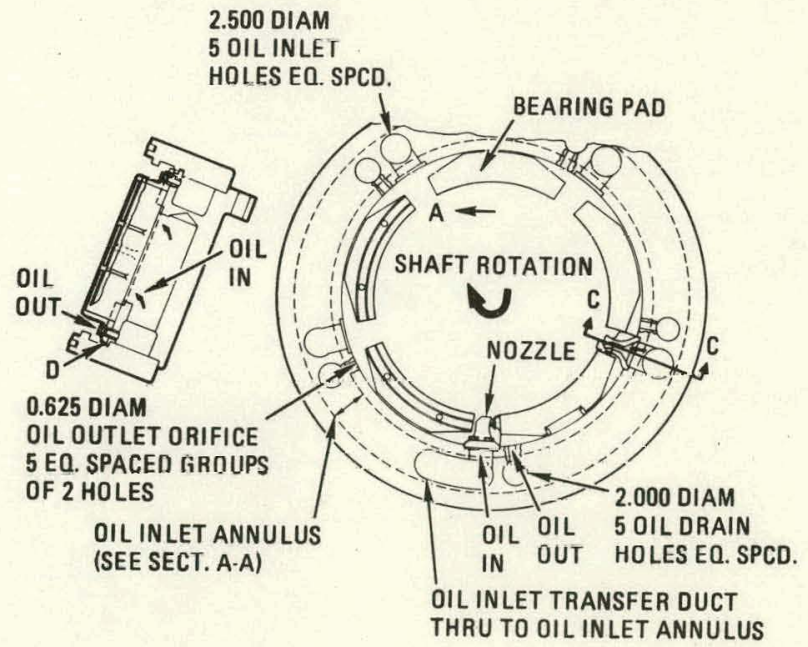

Fig. 19. Journal bearing detajls for helium turbomachine 
Fortunately, most of these forces tẹnd to balance each other, but small differences in areas exposed to the various pressures can produce large changes in axial force. Following detailed analyses, and to provide an adequate margin of safety; the design load for the 400-MW(e) machine was taken to be $90,745 \mathrm{~kg}$ ( 100 tons). To meet this loading requirement, a double-acting tilting pad bearing with a thrust collar diameter of $762 \mathrm{~mm}(30 \mathrm{In}$.$) and eight pads per$ side was designed. The drive to the generator is from the compressor end of the turbomachine, and this permits the thrust bearing to be located external to the PCRV. The reason for external positioning of this bearing is twofold: (1) inspection and maintenance are eased, and (2) it keeps to a minimum the number of ofl lubrication systems inside the reactor vessel. With an outer diameter of $762 \mathrm{~mm}$ (30 in.) and a rotational speed of $3600 \mathrm{rpm}$, the thrust bearing is slightly beyond current thrust hearing experlence. However, it is the opinion of bearing manufacturers who have been consulted that the design is attainable with little more in the way of development than a demonstration test.

\section{Bearing Compartment Seals}

With the journal bearings enclosed within the primary coolant system of the reactor, an important aspect of the turbomachine design is the prevention or minimization of the ingress of lubricants into the primary system. Ingress of ofl into the primary system is to be avoided or minimized, since it can react in a deleterious manner with the reactor core or be deposited in the thermal insulation or on the heat exchanger surfaces. A requirement was established that the bearing compartment leakage should not exceed $0.028 \mathrm{~m}^{3}\left(1 \mathrm{ft}^{3}\right)$ per year. Primary coolant must also be excluded from the bearing compartment since it carries quantities of radioactive material which would contaminate the lubrication system. A detalled study (following an initial investigation outlined in Ref. 3) of the bearing compartment.seals and service systems identified a sealing system which appears to be feasible on the basis of experience with industrial gas turbines.

The selected configuration consists of three seals mounted in serles. The inner two are heliumbuffered labyrinth seals which are backed up by a failure-actuated collar seal. Details of the bearing lubrication and buffering system are shown in Fig. 20. The source of buffering hellum is two parallel supply tanks, each with 1 ts own isolation valve. Two helium-buffered labyrinth seals are positioned in both the compressor and turbine journal bearing compartments. A view of a single element of the seal is shown schematically in Fig. 21. The seal shown is a multistage labyrinth type with the stages in radial steps. These seals ace simllar to the Ljungstrom seals used successfully by the Swedish turbine 1ndustry for many years. In normal operation, purified helium is pumped into the inlet cavity of each seal and flows in two directions through the seal assembly. Approximately $95 \%$ of the buffering helium flows through the large number of knife-edge seals and leaks into the primary coolant flow so as to prevent

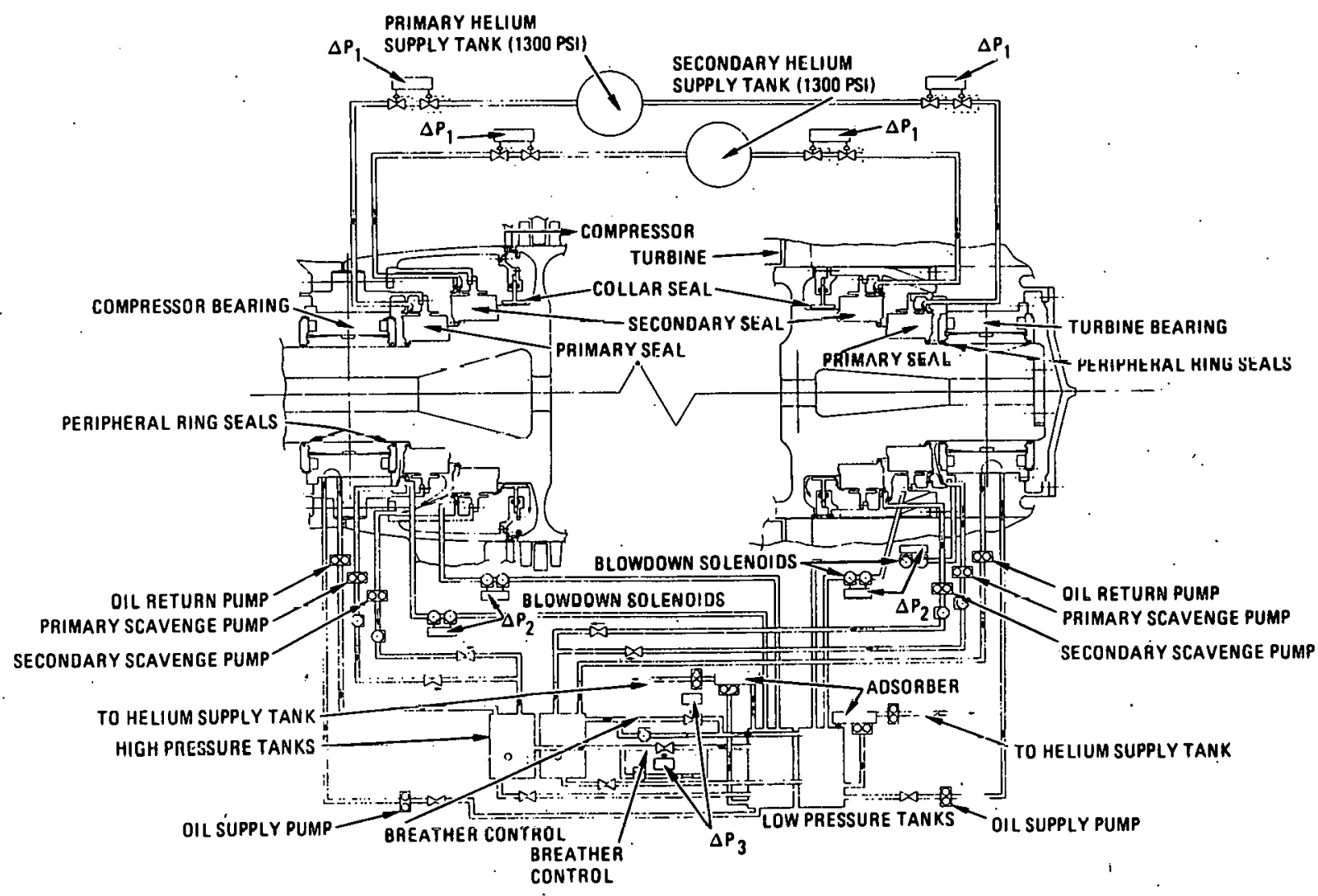

Fig. 20. Bearing lubrication and buffering system for hellum turbomachine 


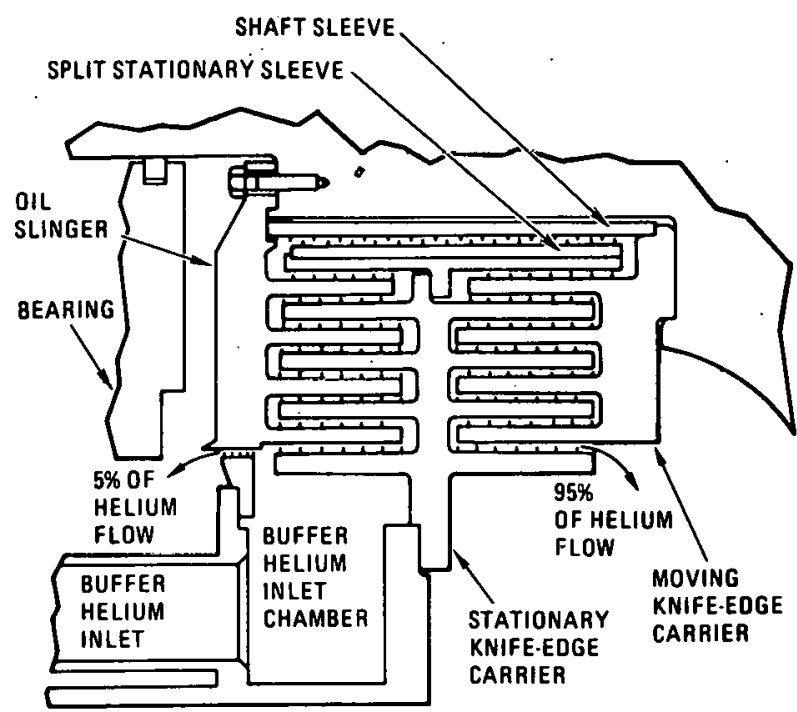

(CLEARANCES EXAGGERATEO FOR CLARITY)

Fig. 21. Detalls of labyrinth seal in bearing compartment of helfum turbomachine

backflow of contaminated primary helium into the bearing casing. The bearing compartment is sealed of $f$ and permits no through flow, except for a small amount of oil and helium mixture which flows back to the separation system.

Inside the aforementioned twin buffer seals, a collar seal has been incorpurated. This is basicaliy a collar around the shaft at a clearance slightly greater than that of the labyrinth seals. The purpose of this seal is to prevent oil leakage into the main helium stream in the event of destructive failure of the labyrinth seals due to bearing or shaft fallure. In addition, the system includes an ofl return pump. It is designed so that during catastrophic faflure, the high-flow supply pump can be shut down while the retum pump scavenges the bearing compartment, thus leaving a smaller quantity availablc for possible ingress into the primary system. A failure mode and effect analysis was performed on the jourtial bearing lubrication and buffering system, and $i t$ revealed no significant concerns.

\section{Turbomachine Cavity Seals}

With the installation of the turbomachine into the horizontal cavity in the PCRV, there are two possibilities for machine-to-primary-system interface:

(1) flanged connections and (2) compartmentalization

of the cavity by means of circumferential seals.

Flanged joints require very close tolerance control between the turbomachine. and the vessel (both of which are subject to deflection due to thermal and creep effects over the life of the plant) and remote mechanicmo for coupling aid ulcuupling. Early primary system studies indicated a preference for the seal concept (as shown schematically in Figs. 12 and 13) baseil on the following: (1) advantage was taken of the cavity compartmentation in that the cavity itself was utilized as the flow boundary, which effectively reduced the turbomachine inlet and exit losses by. virtue of the increased area assoclated with the "integral" plenum; (2) tolerance'flexibility, and motion compliance between the PCRV dind llie turbomechine: alld (3) eased maintenance procedure (1.e., elimination of remote retraction and back-up systems). It was recognized in early investigations that the design of large circumferential seals with minimum leakage characteristics represented a formidable task. The present conceptual design includes utilization of segmented piston ring seals for isolation of the various flow plenums. Although the performance of this type of seal is well known and documented, and can be used as a standard with which other types may be compared, concern exists over use of piston rings of very large size. Current investigations are aimed at the possibility of using a leaf rype seal which can be attached to the basic support structure and seals against the machined outer diameter of the engine case. More confidence exists in establishing the roundness of this case than one incorporated into the support structure.

As shown in a simple form in Fig. 22, the seal arrangement consists of overlapping leaves in two layers fixed at one end to the support structure, with the flexible leaves seated against the case ring. The system ut $111 z$ es the pressure differential across it to create additional sealing force at the interface, thus minimizing leakage.
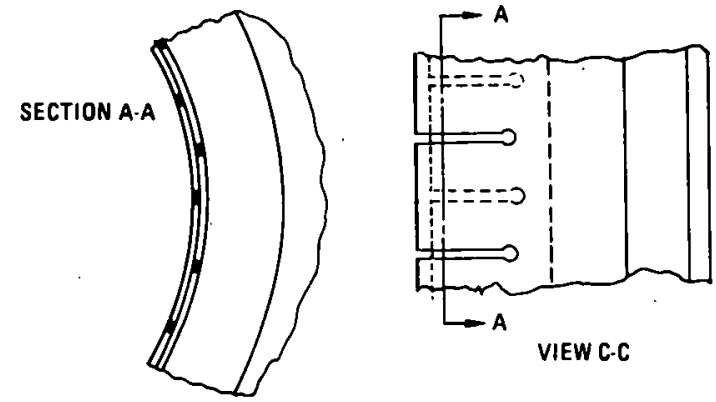

VIEW C-C

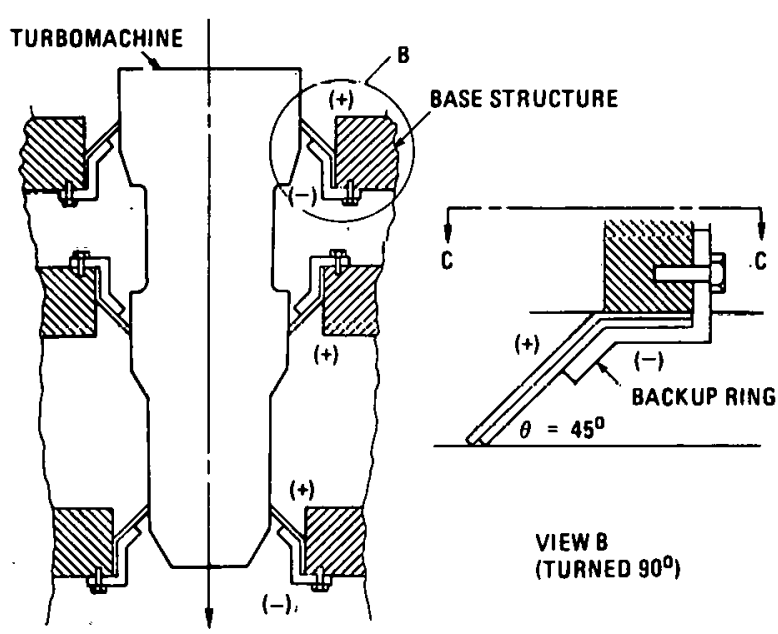

Fig. 22. Details of turbomachine-to-cavity circumferential case seal design concept.

Materials Selection for Helium Turbomachine Design At the onset of HTGR-GT plant studies a philosophy was established, based on conservatism of design and safety, that the power ronversion system components would be designed for the full operating 
life of the plant of $280,000 \mathrm{hr}(40 \mathrm{yr}$ at $80 \% \mathrm{ca}-$ pacity factor). It was recognized that in the case of the turbomachine, the turbine blading, for example, could be replaced in the 40-yr time. Nevertheless, the aforementioned criterion was adopted, and the stress levels in the turbomachine are commensurate with the $280,000-h r$ operating $11 \mathrm{fe}$. Thus, while the turbine inlet temperature is modest compared with current industrial gas turbine practice, the long life requirement necessitates utilization of high-grade alloys.

While the HTGR-GT plant is a long-term project (from concept sclcction to commercialization), the aforementioned conservatism was extended to material selection, and it was felt prudent to base the design on existing materials ( 1 .e., no rellance is made for materlals breakthroughs in the design). From Table 4 it can be seen that for the varlous elements of the turbomachine, exicting materials have been selected. It is recognized that as better materlals are developed and qualified for utility service, they will be factored into the program in a prudent manner.

TABLE 4

MATERIALS SELECTED FOR HTGR-GT PLANT TURBOMACHIN

\begin{tabular}{|c|c|}
\hline Component & Material \\
\hline $\begin{array}{l}\text { Compressor } \\
\text { Disks } \\
\text { Hubs } \\
\text { Blades } \\
\text { Vanes } \\
\text { Cases } \\
\text { Mounts } \\
\text { Ducts } \\
\text { Containment Ring }\end{array}$ & $\begin{array}{l}\text { Ladish D6AC Low Alloy Steel } \\
9 \mathrm{Ni}-4 \text { Co }-0.2 \text { C Steel } \\
\text { AMS } 6414 \text { (AISI } 4340 \text { ) Low Alloy Steel } \\
\text { ASTM A-515 Gr 55 Carbon Steel } \\
\text { ASTM A-387 Gr 12) Low Alloy Steels } \\
\text { ASTM A-217 WC6 (A ) Stainless Steel } \\
\text { AMS 5613 (AISI 410) S }\end{array}$ \\
\hline $\begin{array}{l}\text { Turbine } \\
\text { Disks } \\
\text { Hubs } \\
\text { Blades } \\
\text { Vanes } \\
\text { 8lade Tip Seals } \\
\text { High-Temperature Ducts } \\
\text { Cases } \\
\text { Mounts } \\
\text { Dutts } \\
\text { Containment Ring }\end{array}$ & $\begin{array}{l}\text { Ladish D6AC Low Alloy Steel } \\
9 \text { N1 }-4 \text { Co }-0.2 \text { C Steel } \\
\text { PWA } 658 \text { (IN-100) N1-Base Alloy } \\
\text { PWA } 1447 \text { (MAR-M-247) Ni-Base Alloy } \\
\text { AM } 5783 \text { (Hastelloy S) Coated } \\
\text { ASTM A-515 Gr } 55 \text { Carbon Steel } \\
\text { ASTM A-387 Gr 12) Low Alloy Steale } \\
\text { ASTM A-21\% WC6 } \\
\text { AMS } 5613 \text { (AISI 410) Stainless Steel }\end{array}$ \\
\hline Insulation & PWA 385 (Kaowoo1) \\
\hline
\end{tabular}

The long-term behavior of materfals under a réprésentative reactor environment is being characterized, and the environmental effects on material properties are beling quantitively established. The General Atomic materials screening program represents only part of an overall effort being carried out by several countries to establish materials data for advanced gas-cooled reactor systems. To date, over $25,000 \mathrm{hr}$ have been accumulated in creep and corrosion tests at elevated temperature in a representative helium environment of the HTGR-GT primary circulr. Farticularly encouraging are the results for the baseline candidate nickel-base turbine blade/ vane alloy (IN-100), which shows no apparent degradaLlun in propercies.

\section{Fabrication-Related Design Considerations}

In view of the previously mentioned philusuphy of conservatism in design, ut1lization of existing materials, and established technology, It was an obvious goal to establish a turbomachine design that did not require advancements in the state-of-the-art with regard to fabrication technology $(\mathrm{e} . \mathrm{g} . \mathrm{d}$ disk diameter exiédilig cuiltul futgling $1 \mathrm{lmlits}$ and casings larger than have been cast to date).
For a single-shaft hellum turbomachine (with a rotational speed of $3600 \mathrm{rpm}$ ) in the power range of 400 to $600 \mathrm{MW}(\mathrm{e})$, the rotating section is compact (characterized by small blade helghts) and, as outlined in Table 3 , is substant lally smaller than an equivalent air-breathing machine because of the high degree of pressurization of the helium working fluid (particularly at the turbine exit). The external dimensions of the helium turbomachines discussed in this paper are, in fact, quite similar (as can be seen in Fig. 23) to those of an extsting air-breathing, advanced, open-cycle industrial gas turbine in the 100-MW(e) range. The fact that the hellum turbine (particularly the rotor assembly and casings) is comparable in size to existing machines substantiates the claim that conventional fabrication methods and facilities can be. used. An appreciation for the overall assembly size of the FT-50 $100 \mathrm{MW}(\mathrm{e})$ open-cycle industrial gas turbine can be gained from Fig. 24

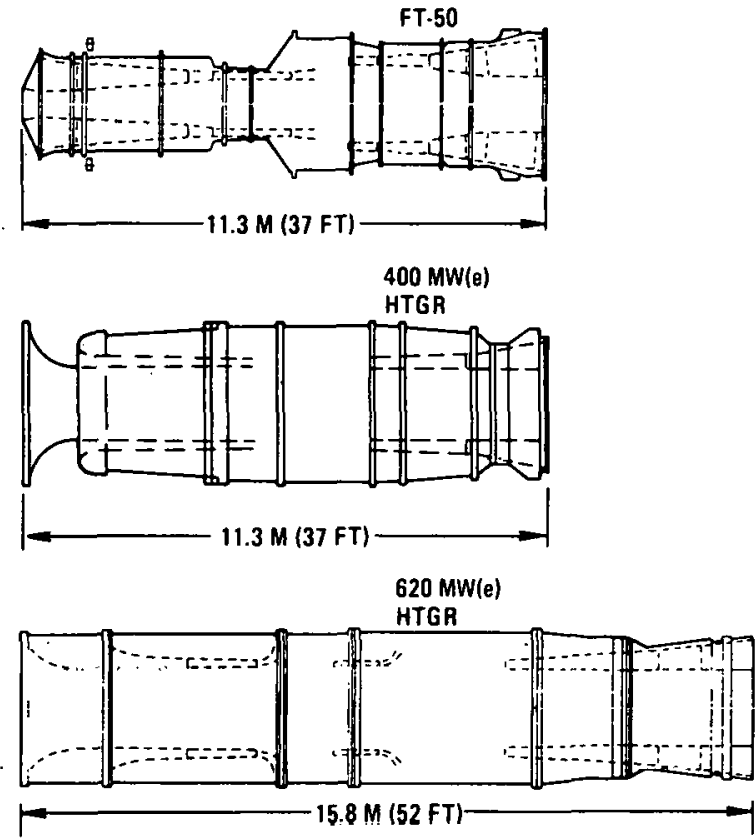

Fig. 23. Overall turbomachine envelope comparison for open- and closed-cycle gas turbines

\section{TURBOMACHINE MAINTENANCE CONSIDERATIONS}

For the Integrated system it is Important that turbomachine maintenance aspects be considered during the plant conceptual design phase. The primary objective of the HTGR-GT maintenance plan is to provide facilities, equipment, and components of reasonable cost that will yield good plant avallability. It is therefore a matter. of policy to design the reactor and conversion system installation, as well as the related maintenance facilities, for practical opera$t 1$ on for both planned and unplanned maintenance.

The turbomachine will be serviced in scheduled inspection and maintenance programs that are intended to minimize maintenance costs while still providing assurance that the equipment is functioning within design structural and performance limits. Major maintenance w1ii be pertormed on a 6-yr incerval. While removal of the turbomachine is considered to be 


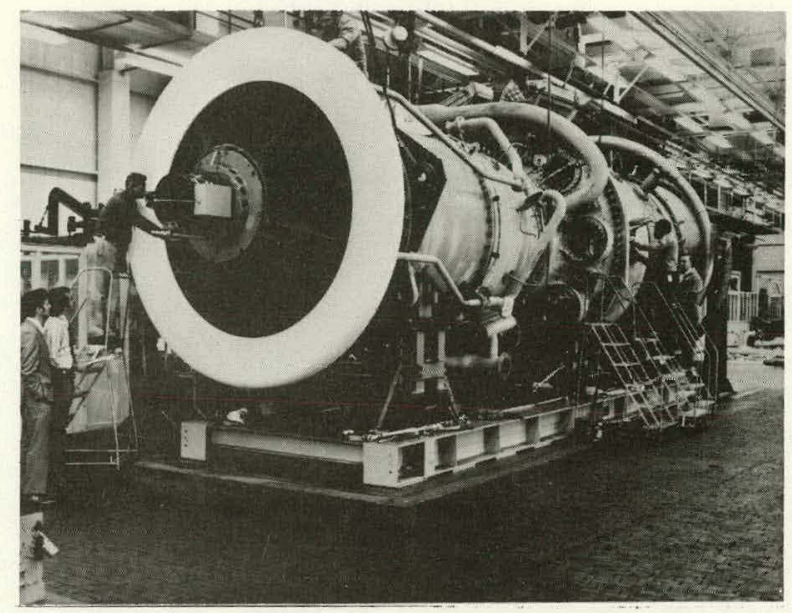

Fig. 24. View of overall assembly of FT-50 100-MW(e) open-cycle industrial gas turbine

a scheduled maintenance operation, current maintenance philosophy for a mature commercial plant is that the turbomachine will be removed only if the condition monitoring system indicates a problem. The reliance on diagnostics to indicate operating problems, together with turbomachine maintenance philosophy, is summarized in Table 5 .

TABLE 5
HTGR-GT TURBOMACHINE MAINTENANCE PHILOSOPHY

- Reliance on Diagnostics To Indicate Operating Problems Temperatures

Pressures

Vibration Monitors

Visual (Fiber Optics)

On-Line

Pirect Contact and Gas-Coupled Emission Transducers

Clearances and Eccentricities

Magnetic Metal Chip Detectors in

Lubrication System

Oil Spectrometric Analysis

- Primary System Shemistry

- Turbomachine installation and removal procedures are established. Current design requires man access into the purged areas for trive coupling, service system line flanges.

- Fur a mature commercial. plant, the turbomachine will be replaced only if the diagnostic system indicates problems.

with the full 280,000-hr plant operallug life (i.e., nn 1 ife-límited subcomponents). Journal bearing areas are accessib

In situ balancing of rotor is considered possible by UTC.

- Alignment of the turbomachine-generator is not considered a problem.

- For many maintenance operations, experience from industrial gas turbines is directly applicable.

It is recognized that the turbomachine internal surfaces will become radioactively contaminated by deposition of helium-borne condensable fission products. Thus, a procedure must be established for remote removal of a failed machine and replacement with a spare unit. For a multiloop plant, downtime will be he1r to a minimum by performing turbomachine change-out during a scheduled retueling perivu. Following a preliminary maintenance study (20), an indepth investigation has been carried out by General Atomic Company and United Technolugies Corporation to establish a procedure (and the necessary equipment) for remote handling maintenance. It has been determined that essentially all disassembly and decontamination can be handled remotely, and since this will he a topic of a forthcoming paper, it is merely summarized below.
The turbomachine is being designed to permit easy disassembly and rebuilding. A procedure has been established for remote disassembly of the machine, and the view shown in Fig. 25 represents an initial operation in an on-site maintenance facility. Parts of the turbine and compressor stator cases are of split design, and this together with other design features permits the compressor and turbine rotor assemblies to be split into modules as illustrated in Fig. 16. Decontamination of each rotor can be carried out separately, since it is expected that fission product plate-out will be more severe on the turbine rotor than on the compressor components. Following decontamination of the major subassemblies, the separate rotor sections and split stator cases can be disassembled into parts without the need for remote manipulators. A goal for the rebuilding of a used turbomachine, with replacement of subcomponents as necessary (perhaps turbine blades in the first stages), would be to perform this operation in a straightforward "hands-on" manner.

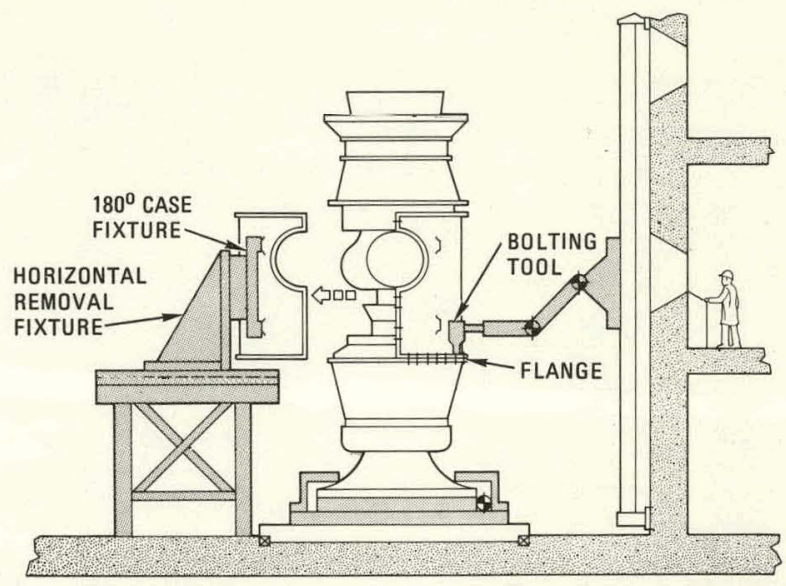

Fig. 25. Diagram showing an initial operation in the remote disassembly of a contaminated helium turbomachine

For the direct-cycle HTGR-GT plant, the issue of in service inspection (ISI) has added importance, since all the power conversion system componenls die installed inside the PCRV and are thus not accessible for direct visual inspection. In-service inspection requirements are continually becoming more demanding to satisfy various code requirements, regulatory guides, and licensing commitments and to meet utility owners' needs. It is therefore prudent to consider ISI requirements during the plant conceptual design and to pursue a policy of providing inspectable decigns where required. While in a very early stage of development, an on-going study has beell aimed at identifying the type of inspection envisioned for key elements in the major components. Provisions are incorporated in the turbomachine desigu to permit borescope inspedtion of highly stressed areas while the turbomachine remains installed in the PCRV cavity. A summary of the ISI examination and testing possibilities for the turbomachine is given in Table 6 . It should be emphasized that these possibilities are tentative and will require special attention in developing a program of ISI and testing as the turbomachine and plant designs mature. 
TABLE 6

HTGR-GT TURBOMACHINE ISI POSSIBILITIES

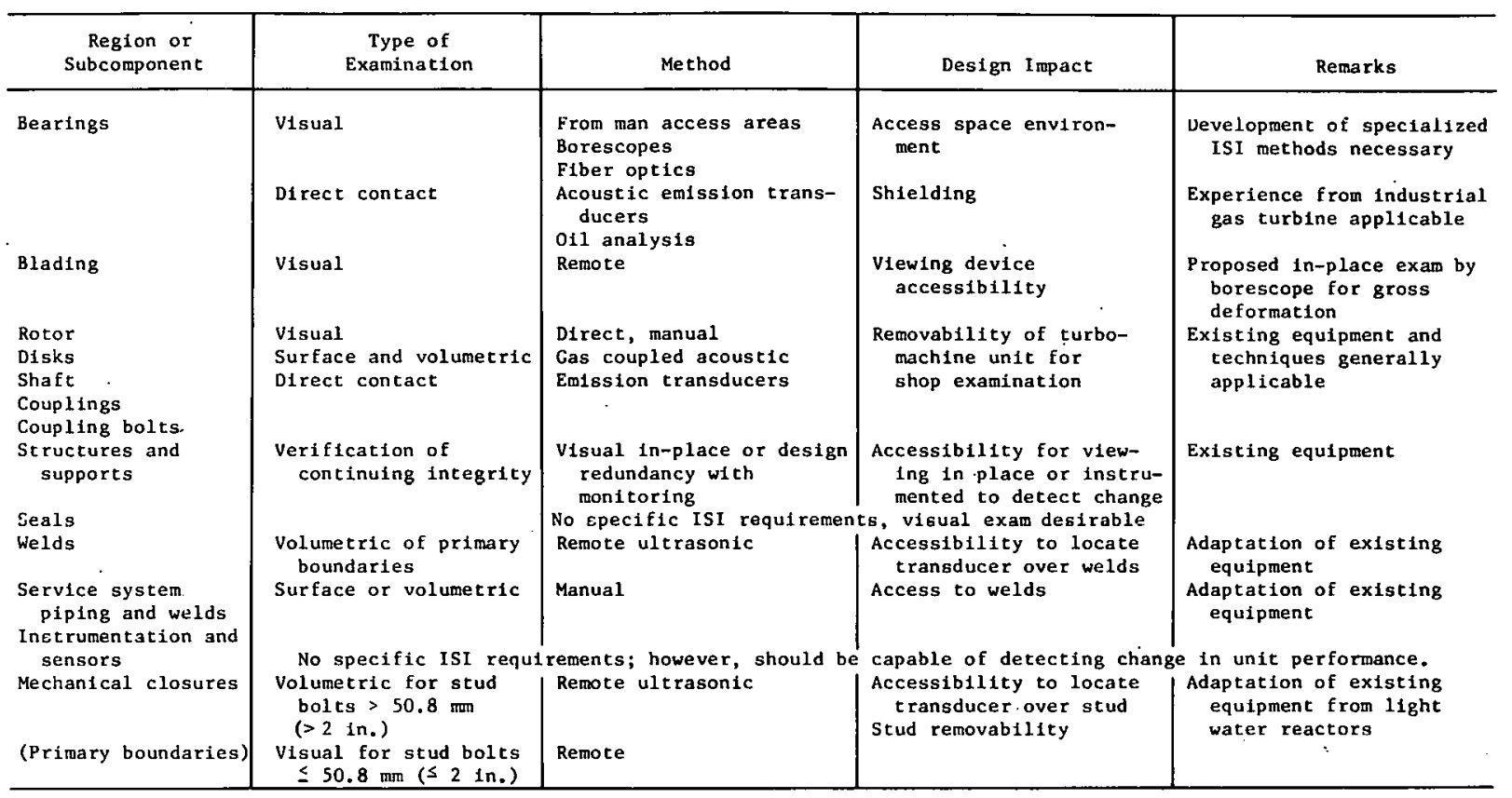

\section{TURBOMACH INE DEVELOPMENT}

While no advancement of turbomachinery stateof-the-art is needed, several years of in-depth design work, in conjunction with a comprehensive development effort, is necessary to realize the goal of progressing from the present conceptual design stage to plant commercialization in about $15 \mathrm{yr}$. In this paper the formidable technology bases for the design of the helium turbomachine have been emphasized. Another point that should be made is the conservative nature of the turbomachine by virtue of the following:

- Low turbine inlet temperature.

- Low rotor speed.

- Known materials.

- Low stress levels.

- Iniform temperatures.

- Non-corrostve working fluid.

- Modest load-following operation cycle.

- All known technologies.

- Industrial design practice.

The development of the turbomachine w11l essentially consist of extensive component testing and installation checkout in the PCRV. The following component testing is planned:

- Bearing and seal tests.

- Lubricating system tests.

- Flow distribution tests.

- Compressor rig tests - 1/2 scale.

- Tuiblné rig tests - 1/2 scale.

- Disk and rotor burst tests - blade loss tests.

- Shaft seal tests.

- Materials compatibility tests.

- Full-scale spin test.

The installation checkout (at zero power) in the

PCRV will consist of the following:

- Pressurization checks.

- Turbomachine spin and balance test.

- Motoring checkout.
- System simulator test.

- Lubrication/buffering system checks.

- Instrumentation

The rise to full temperature operation will be done over a period of a few months with nuclear heat input. If problems are encountered with the turbomachine during this period, it is projected that they can be remedied in a straightforward and $t$ imely manner since the contamination level will be very low, as evidenced by experience at the Fort St. Vrain HTGR plant where maintenance work was performed on the helium circulators without difficulty.

SUMMARY

Since closed-cycle gas turbines are not well known in the U.S.A., a predominant theme in this paper has been to emphasize that helium turbomachines of large power rating [400 to $600 \mathrm{MW}(\mathrm{e})]$ bear a close resemblance to existing large open-cycle industrial gas turbines. The aerodynamic procedures used for a helium turbomachine are essentially identical to conventional alr-breathing gas turbine practice. The high degree of pressurfzation in the closed-cycle system results in a compact arrangement, and it has been shown that helium turbomachines in the 400- to 600MW(e) range are similar in overall size to existing industrial gas turbines in the 100-MW(e) class. In addition to existing mechanical design methodology being applicable, an important aspect of the above size comparison is that conventional fabrication methods and facilities can be used for the helium turbomachine.

Emphas 1s has been placed on the formldable technology bases from which the design and development of the helium turbomachine can benefit. While this paper has been predominantly design-related, it was felt pertinent to comment on existing hardware and to point out that large multistage, axial-f low helium 
turbomachines have operated successfully in Europe. Between now and the year 2000 , when it is projected that the HTGR-GT plant could become a commercial option, it is postulated that significant technology advancements (materials, aerodynamic, etc.) could impact on the performance of the plant. During the conceptual design of the plant, however, it was felt prudent to use exlsting state-of-the-art technology, and in the case of the turbomachine, the conservative nature of the design (and performance est Imates) reflects the influence of technology from demonstrated 1ndustrial gas turbines. Advancements In materials and design methodology and Improved component efficlencles w1ll be factored into the plant as the design matures.

For the HTGR-GT plant an extensive program of design, development, and testing is necessary to achieve the performance and structural integrity to qualify the equipment for nuclear power generation. This paper has emphasized salient factorg related to the helium turbomachine, since it represents the single most important component in the plant. Crit1cal elements of the turbomachine, such as the bearings and seals, have been 1 dentified, and in these areas development work is necessary. The formulation of test plans and the design of specialized rigs, from which data will be needed for the final machine design, are in progress.

In summary, it is projected that rigorous development attention must be given to areas that impact the operation of the machine when installed inside the reactor vessel (i.e., bearings, seals, structural integrity, etc.). However, because of its overall simplicity and modest operating temperature, the helium turbomachine is not regarded as any more difficult a development problem than a new hightemperature aircraft gas turbine.

\section{ACKNOWLEDGMENTS}

The authors would like to thank General Atomic Company and United Technologies Corporation for permission to publish this paper. Work on the HTGR-GT plant turbomachine has been supported by the U.S. Department of Energy under Contract DE-ATO3-76SF70046. Design-work on the helfum turbomachine has been done by the Power Systems Division and Pratt and Whitney Aircraft Division of Unt ted Technologies Corporation, under subcuntract to General Atomic Company.

REFEKENCES

1 McDonald, C.F., and Boland, C.R., "The Nuclear Closed-Cycle Gas Turbine (HTGK-Gl') - Dry Cooled Commercial Power Plant Studies," paper to be presented at the 25th ASME Gas Turbine Conference, New Orleans, Loutsiana, March 1980.

2 Adams, R.G., and Boenig, F.H., "The Des1gn of the Turbomachinery for Gas Turbine High Temperature Gas Cooled Reactor Power Plant," ASME Paper No. 77-GT$30,1977$.

3 Adams, R.G., et. al., "Bearing Compartment Seal Systems for Turbomachinery in Direct Cycle HTGR Tower Flduls," A3ME Paper No. 78-GT-38, 1978.

4 McDonald, C.F., "The Nuclear Closcd-Cycle Gas Turbine (GT-HTGR) - A Utility Power Plant for the Year 2000," AIAA Paper 79-0191, 19 7y.

5 Keller, E., "Forty Ycars of Experience on Closed-Cycle Gas Turbines," Annals of Nuclear Energy, Vo1. 5, No. .8-10, 1978, pp. 405-422.

6 McDonald, C.F., "The Closed-Cycle Gas

Turbine - Present and Future Prospectives for Fossil and Nuclear Heat Sources," ASME Paper No. 78-GT-102, 1978 .

7 Zenker, P., "The Oberhausen $50 \mathrm{MW}(\mathrm{e})$ Helium Turbine Plant," Combustion, Vol. 47, No. 10, 1976 , pp. 21-25.

8 Weber, D., "Hellum Turbine Explores Future Nuclear Application," Energy International, Vol. 15. Apri1 1978, pp. 47-50.

9 Noack, G., et al. "Significance of the Helium Turbine Plant at Oberhausen (EVO) and of the High Temperature Test Facllity at Jillch (HHV) for the Development of the HTGR Direct Cycle Systen (HHT)," Symposium on Gas-Cooled Reactors with Emphasis on Advanced Systems, Jullch, Germany, October 1975, Vol.

II, IAEA, Vienna, May 1976, pp. 189-200.

10 Haselbacher, H., and Eiermann, A., :

"Development of Hellum Gas Turb1ne Systems in the Nuclear Fleld," ASME Paper No. 74-GT-123, 1974.

11 Endres, W., "Large Helium Turbines for Nuclear Power Plant," ASME Paper No. 70-GT-99, 1970.

12 Haselbacher, H., et al., "HHT Hellum Turbine and the HHV Plant," Paper No. A4/21 presented at Nuclex 78, Basel, Sw1tzerland, October 3-7, 1978.

13 Haselbacher, H., "Closed-Cycle Gas Turbines for HTR Nuclear Power Plants and LNG Regasification Plants," Brown Boveri Review, Vol. 66, No. 2, Feb. 1979, Pp. 120-129.

14 McDonald, C.F., et a1., "Primary System Design Studies for Advanced Direct Cycle Nuclear Gas Turbine Plant," ASME Paper No. 77-GT-25, 1977.

15 Kammerze11, L.L., "HTGR-GT Systems Optimization Studies," paper to be presented at 25th. ASME International Gas Turbine Conference, New Orleans, March 1980 .

16 Dvorak, H.G., and Rogers, W.H., "An

Advanced Industrial Gas Turbine for Utility Generation," Proceedings of the American Power Conference, Vo1. 37, Apr11 1975, pp. 352-362.

17 de Blas1, D., "FT 50 Design Shortcut to 1980 Technology," Gas Turbine World, Vol. 5, Nov. 1975, pp. 9-15.

18 Chmielewski, R., et al., "Fault Analyses of the Gas Turb1ne HTGR," ASME Paper 76-GT-99, 1976. $19 \mathrm{Hagg}, \mathrm{A} . \mathrm{C}$., and Sankey, G.0., "The

Containment of Disk Burst Fragments by Cylindrical Shells," Journal of Engineering for Power, Vol. 96, Ser. A, No. 2, April 1974, Pp. 114-123.

20 McDonald, C.F., and Paget, J.A., "Ma1ntenance Considerations in the Design of the DirectCycle Nuclear Gas Turbine Power Plant," ASME Paper No. 79-GT-116, 1979. 